Portland State University

PDXScholar

1971

\title{
Foreign policy decisions which led to United States military occupation of the Dominican Republic
}

Bert Lewis Junior Farrar

Portland State University

Follow this and additional works at: https://pdxscholar.library.pdx.edu/open_access_etds

Part of the Diplomatic History Commons, Political History Commons, and the United States History Commons

Let us know how access to this document benefits you.

\section{Recommended Citation}

Farrar, Bert Lewis Junior, "Foreign policy decisions which led to United States military occupation of the Dominican Republic" (1971). Dissertations and Theses. Paper 1463.

https://doi.org/10.15760/etd.1462

This Thesis is brought to you for free and open access. It has been accepted for inclusion in Dissertations and Theses by an authorized administrator of PDXScholar. Please contact us if we can make this document more accessible: pdxscholar@pdx.edu. 
AN ABstract of THE THEsIs or Bert Iewis Junior Farxar for the Haster of Art: In History presented April 14, 1971.

Title, Foreign Pollcy Decleions Which led to United states Mlltary Ocoupation of the Dominlean Republic.

APPROVED BY MEMBERS OF THE THESIS COMITTEB:

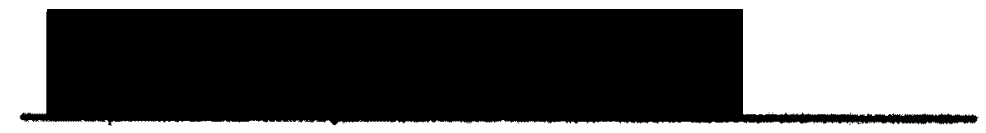

Frederick Nunn, Chairman

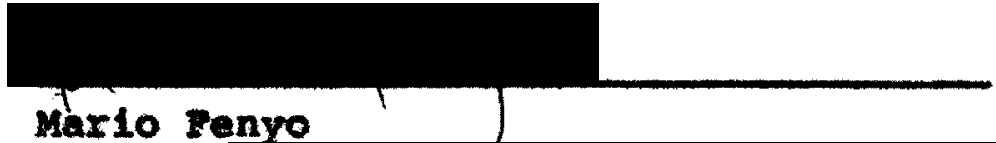

Elllot Benowit:

To achleve Independence, the Dominican Republic had to first endure three centuries of heavy-handed Spanish rule and period of Haftian domination that lasted for twenty-two years. Fear of Haltian reconquest, however, conpinced the leading Dominican politicians that the new nation could not long endure without forelgn protection. Encouraged by Dominican offers of a naval base, the United states toyed with the idea of expansion in the CarIbbean as early as 2850 , but alvil war cut short these notions and allowed spain to reassert control over her 
formar colony. Although Spanish occupation onded in failure the United states becams more determined that the 1sland Republic should never agaln be dominated by a Buropean power.

Such a datermination on the part of the Onited Btates to prevent European incuraion led to an abortive annexationist attempt by the Grant administration in 1869 and to the establishmont of a custom recuivership in 1905, when unpald forelgn debte axoused the 1re of European ereditors. It was hoped that the establimhment of a custom receivership would usher in a period of peace and prosperity for the Dominicans, but by 1912 1t becane evident that such hopes wexe not to be realized. president wiloon adhered to the axgument that forelgn intervention in the Caribbean was not to be tolerated but broadened Onited states involvement in the domestio policies of the Dominican republic by insiating on the establishwent of a constitutional democracy, whioh he felt would establich domeotic tranquility. When 1t became apparent that the internal conditions of the laland republic were not improving. W11son reluctently ordered in the Onited states Marines In the hopes that they would be able to educate the Dominleans to the ways of democracy. By broadening the scope of United states involvemont in the dowatic affalrs of the Dominican Ropublic, 
Wilson had produced an occupation that denied the Dominicans the inherent right of a nation to govern itself, a 11berty which had been maintained against overwhelming odds during the preceding seventy-two years. 
FOREIGN POLICY DECISIOAS WHICH LED TO UNITED STATES MILITARY OCCUPATIOA OF THE DOMTMICAN REPUBLIC

by

BERT LEWIS JUALOR TARRAR

A thesls submitted in partial fulfillment of the requirements for the degree of

MASTER OF ARTS

in

EIsToRx

Portland state University

1971 
TO THB OFICS OF GRMDATE STUDIES:

The member of the comaltee approve the thesls of Bert Lowi Junlor Ferrax presented Apr11 14, 1971.

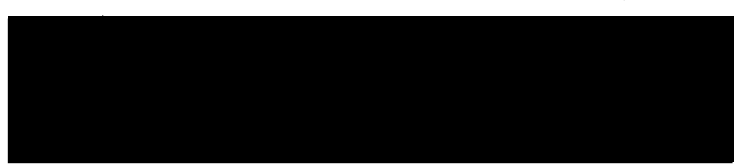

Frederlok Nunn, Chalrmen

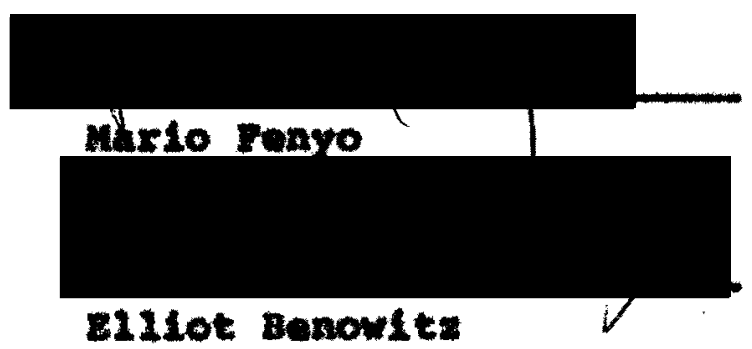

MPphovet

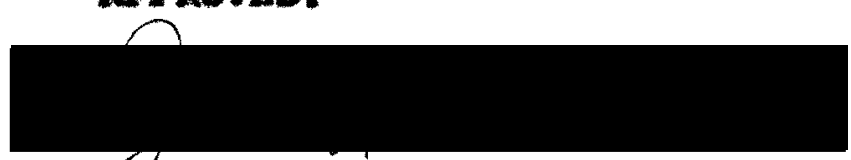

Jaber I. Gilmore.

Head. Dopartment of History

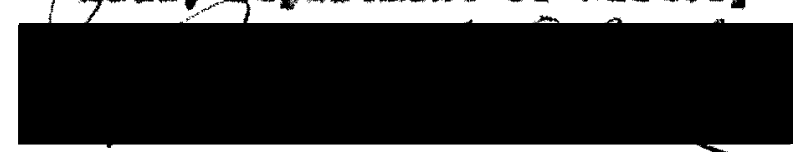

David T. Clark.

Dean of Craduate Btudie:

Apr11 25, 1971 
TABLE OF COATENTS

PAGE

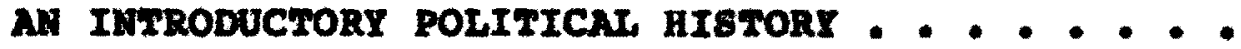

CHAPHER

I THE MNEXNTIONIST IEnRE $\cdot \cdot \cdot \cdot \cdot \cdot \cdot \cdot$

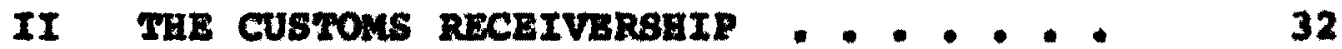

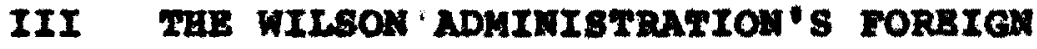

POLICY IN THE DOAIMICNH REPUBLIC • • • 56

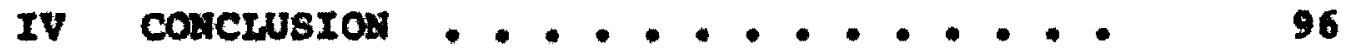

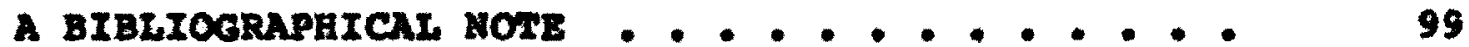




\section{AN IHTRODUCTORY POLITICAL HISTORY}

The Island of Hispaniola was discovered in 1492 by Christopher Columbus who took possession in the name of the King and Queen of Spain. From this date forth the island was to be a victim of outglde forces. For over half a century the island was the capltal of the Spanish empire in the Americas. With the discovery of gold and silver in Mexico and Peru, however, her importance dwindled raplaly in the eyes of the Spanish Crown. By 1650 she had become an abused power in Spain's wars with France and England and in 1697 the western portion of the lsland was formally ceded to France.

Left to pursue her course in relative peace the Spanish colony of Santo Domingo experienced a brief cultural and economic revival by the middle of the eighteenth century. By the end of the century, however, she found herself emersed in the turmoll of the Haitian revolution and endured military occupations by the three great colonlal powers of Spain, France, and England.

In 1821 a conspiracy led by José Nuñez de Cáceres expelled the Spanish authority and Santo Domingo was declared independent. Within a matter of weeks, however, President Jean Plerre Boyer of Haitl declared the people of Santo Domingo to be subject to the laws of haiti and occupied the 
country with troops. Opposition steadily mounted and in 1844 the Haitian yoke was overturned and the Dominican Republic was established.

From 1844 to the end of the century three men dominated Dominican history. They were Pedro Santana, Buenaventura Báez, and Ulises Heureaux. Both Santana and Báez feared Haitian reconquest and sought the assistance of foreign powers in helping to maintain the Republic's independence from Haiti. The pursuit of such policies led to the re-establishment of Spanish control from 1861 to 1865 and aroused a greater determination by the United States that the tiny Republic should never again be dominated by a foreign power. This attitude in turn produced an abortive annexationist attempt by the Grant administration in 1869. During the $1870^{\prime} \mathrm{g}$ the tiny Republic reeled under a series of revolts. Not until 1882 was political stability established under the rule of Ulises Heuxeaux. His geventeen years of dictatorial rule were characterized by a suppression of Constitutional liberties and the accumulation of a foreign debt that approximated thirty-two million dollars by the time of h1s assassination in 1899. Chaos followed Heureaux' death and the country went still deeper in debt. In order to stave off the possibility of a European intervention designed to collect money due their nationals, the United States government, on the request of 
Dominican President Carlos F. Morales, took over the collection of import duties throughout the Republic. Under President Ramón Cáceres (1906-1911) progress was made towards the liquidation of the foreign debt, political stability prevailed, constitutional reforms were introduced and the economy began to prosper. In 1911, however, Cáceres was assassinated and chaos returned. In 1914 the united states government intervened to insure an honest election and tried to persuade the new president, Juan Isidro Jiménez, to accept certain economic and political reforms. When Jiménez was ousted by a revolution in 1916 President wilson sent in United States Marines to occupy the country. Although well intentioned, the occupation, which lasted until 1924, was 111 received by the Dominicans who wanted freedom rather than reforms in education, sanitation and public works. 


\section{CHAPTER I}

\section{THE ANNEXATIONIST YEARS}

In 1821, Insplred by the efforts of simón Bollvar. Dominicans succeeded in gaining their freedom from spain. Within a few short weeks, however, they were conquered by nelghboring Hait1 who asserted her authorlty over them unt1l 1844. From the outset the Republic's second period of independence was marked by political violence and insurrection. Added to her miaery was the fact that from time to time the Haitians attempted to restore their authority by force. Living in constant fear of Haitian Invasion Dominican politicians appealed abroad to the United states, France, Spain, and Great Britain for protection. While the United States was engaged in Civil war Spain reannexed her former colony only to withdraw in 1865 because of high occupation costs and the decimation of her army by native uprisings and yellow fever. Though short-11ved, Spanish Intrusion aroused a greater determination by the United states that the Dominican Republic should never again be dominated by a foreign power. Washington's interest in repeated Dominican offers of a treaty providing for annexation of the Dominican Republic to the United States was spurred also by the fact that the fine harbor at Samand Bay was poten- 
tially one of the most strategic positions in the west Indies.

North American relations with the 1sland of HispanLola commenced in the first decades of the elghteenth century when Yankee skippers ventured forth Into the caribbean sea in search of trade. This inter-imperial trade, made possible by the abundant productivity of the British colonies in America, was of course, illegal, but:

- Bo strong were these trading instincts and
so rich were the rewards from this illicit com-
merce that differences of race, religion, and
nationality were lightly regarded. Even the
many wars that vexed old Europe failed to destroy
these colonial connections.

With the waning of Spanish power in the seventeenth century, the French contrived to gain a foothold in the western extremity of Hispaniola, efforts made by spain to dislodge them proved futile, and by the Treaty of Ryswick In 1697 the western third of the island was formally ceded to France. Through the efforts of the French planters, the colony of saint-Domingue, as it was called, became one of the most fertile and productive regions in the New World, and the most precious overseas possession of France. Here was centered a rich plantation cconomy which provided sugar and coffee for European tables but which lacked a supply of salt meat, salt fish, and flour to feed the thousands of

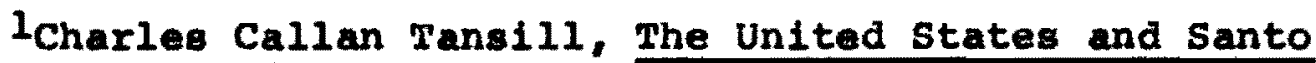
Domingo, 1798-1873: A Chapter In Caribbean Diplomacy (BaIEimore: John HopkIns Pregs, I938), p. $I$. 
Negro slaves who cultivated the valuable crops. France could not furnish the thriving colony with enough cheap meat, but the British North American colonista could. Soon Yankee traders were supplying the French planters with fish, salt meat, livestock, flour, rice and other provisions in return for augar and molasses. French attempts to Impose limitations on the trade repeatedly net with fallure. The importance of this lucrative trade was stated by John Adams in 1783 when he declared that "so essential is this commerce to both parties that if the governments forbid $1 t$, it will be carried on clandestinely. $* 2$

In the first weeks of August 1791, several Negro leaders formulated plans for overthrowing the hated slave owners of Haiti. By September the revolt had spread throughout the colony. The United states government at first "extended assistance to the colonial administration in Haiti through payments upon the national debt owed to France," 3 but the whites, outnumbered eleven to one, were slaughtered in large numbers and were gradually forced from the island. After a series of costly wars the Negro leader Toussaint 1 overture led the blacks to victory in Haiti and by 1801 secured control over the whole of Hispaniola. HIs success, however, was only temporary. Napoleon, free from

2The Works of John Adams, ed. by C.F. Adams 110 vols, Boston, 1854, VIII, p. 79, quoted in Tansill, op.c1t., P.3. 3Tansi11, op.c1t., p.8. 
entanglement in Europe, Imediately organized a milltary expedition, under General victor Le Clerc, to recover Santo Domingo. Toussaint was forced to surrender, and was later captured and imprisoned in France where he died within a year. The French, however, presently faced a new series of revolts led by the capable Negrc commander, Jean Jacques Dessalines. The French position soon became a defensive one. By the end of 1802 yellow fever had ravaged the French army and killed its commander and when the Peace of Amiens was broken by warfare in 1803 Napoleon decided he could ill afford to dissipate his strength in quest of empire west of the Mississippi. An astute Thomas Jefferson, realizing that without Hispaniola as cornerstone the proposed French Empire in the West was at best a shaky structure, sent James Monroe to aid the American Minister at Paris, Robert Ilvingston, in negotiating sale of the Floridas and New Orleans. Napoleon, realizing failure in Hispaniola, and knowIng full well that England might land an axmy in Louisiana and hold the territory by right of conquest, endeavored to win the good will of the United States, and thereby keep her from forming an alliance with England, by selling the Loulsiana Territory in 1 ts entirety to the United States government for fifteen million dollars.

The French were able to maintain themselves in Santo Domingo (the Spanish portion of the 1sland) unt1l 1809 when a national insurrection, aided by Spanish and English 
troops succeeded in expelling them forever. The people of Santo Domingo then accepted the rule of Spain unt11 1821 when a Republic was proclaimed. Independence, however, lasted only the few weeks that it took the president of liaiti, Jean Pierre Boyer, to occupy the country.

Haitian rule (1822-44) was a period of social and economic retrogression for Dominicans. Every effort was made to Haitianize the country by extending the Haitian laws, and imposing Haitian administrators and governors who ruled with an Iron hand. Through the systematic use of terror Spanish families were forced from the island and their lands resettled by Haitians. The University of Santo Domingo, one of the oldest in the Western Hemisphere, was closed. With the expulsion of all Spanish priests the clergy deterforated and many churches were left without priests. Misery was widespread and "public spirit seems to have sunk so low that only rarely were any sporadic efforts made to raise the standard of a new rebellion." 4 The following report submitted to the British Parliament in 1826 by the British Consul-General in Halt1 provides a graphlc description of the effects of Haitian rules

The whole isle is divided into departments, arrondissements, and communes. These are all under the command of military men subject only

${ }^{4}$ Sumner Welles, Naboth's Vineyard, the Dominican Republic 1844-1924 (2 vols.) New Yorks Payson CIarke Ltd., 1928), I, Pp. 51-2. 
to the control of the president, and to them is entrusted exclusively the execution of all laws whether affecting police, agriculture or finance. There is not a single civilian charged with an extensive authority . . . During the past two years trade has gradually fallen off and.. . It is supposed that it has decreased nearly one half - - The most important code is the Code Rural. the chlef character of which is the enforcing of labor. It is a modification of the old French regulations sanctioned by the Code Noire, with additional restrictions. The provisions are as degpotic as those of any slave system that can be conceived. The laborer may almost be considered as "adscriptus glebe," he is deemed a vagrant and liable to punishment if he ventures to move from his dwelling or farm without license. He is prohibited from keeping a shop. No person can build a house in the country not connected with a farm. - . The code affixes the penalty or fine in some cases, and there is indefinite imprisonment at the option of the justice of the peace. Cultivation would not go on beyond that which daily necessities might require, except for the code. The decrease in population in thirty-three years has been very nearly one-third of the whole population in 1793 . . The covernment has appropriated all the church property to 1 ts own use. The clergy rely wholly on the fees, two-thirds of which they are obliged to pay into the Treasury. . . It is not a subject of surprise that morality should be in as low a stage - . Marriage 1s scarcely thought of.. $.5^{\mathrm{a}}$

under Boyer, however, trade with the United States once again quickened so that by 1822 "the value of American exports [to the 1sland of Hispaniola] was equivalent to the combined exports to Russia, Prussia, Sweden, Denmark and

5 From a report of Charles McKenzie, British ConsulGeneral in Halti, submitted Septembex 8,1826 , by the Rt. Hon. George Canning to Parliament, quoted in Welles, op.cit., I, pp. 52-3. 
Ireland." 6 Although lucrative comercial relations bound the United States to Hispaniola, the government in Washington refused to establish a diplomatic post. The maln reason diplomatic recognition of Boyer's government was not forthcoming was because of the ticklish slavery question. Representatives from the south were particularly vehement in their denunciation of proposed Haitian recognition. Their position was well outlined by Senator Benton of Missouri in 1826 when he stated thats

We purchase coffee from her, and pay for $1 t$, but we interchange no consuls or ministers. - . And why? Because the peace of eleven states will not permit the fruits of a successful negro ingurrection to be exhibited among them. . . . It will not permit the fact to be seen, and told, that for the murder of their masters and mistresses, they are to find frifends among the white people of these United States. 7

It was not until 1844, the year in which the Dominican Republic gained its independence from Haiti, that the united states entered into official diplomatic relations with the 1sland of Hispaniola. After abortive attempts at seeking European assistance, Dominican President Pedro Santana,8 fearing an invagion attempt by General Charles Hérard of c1t.. $\frac{{ }^{6} \text { N1les' Register, }}{120_{0}}$, p. 49 , quoted in Tansill, op. ${ }^{7}$ Register of Debates in Congress, 19 Cong., 1 sess., p. 330 , quoted in ransil1, Op.c1E.. P. 122 .

${ }^{8}$ santana was president three times. His terms were as follows: November 13,1844 -August 4,1848 , February 15 , 1853-May 26, 1856, January 31, 1859-March 18, 1861. 
Haiti and wishing to establish a treaty of friendship and commerce, sent Dr. José M. Caminero as special envoy to the United states to obtain recognition. Within $81 \times$ weeks' time Secretary of state John C. Calhoun, at the urging of President John Tyler, sent a special agent, John Hogan, to the Dominican Republic to obtain information concerning the resources and internal conditions of the island. In Hogan's opinion the island was of "inestimable value" and had "one of the most admirable positions which the world can exhibit for a commercial emporium." 9

The administration of James Polk, however, desired more information and in the spring of 1846 entrusted a fact finding mission to a young naval lieutenant, David D. Porter. Porter's observations were critical in many respects. He recognized the presence of valuable mineral deposits and delighted at the harbor potentialities of Samaná Bay but of the climate he remarked that "the air at night is filled with poisonous flies, and mosquitoes drive one almost mad," while as to the constitution of the Republic he believed that for the present, "It might as well never have been adopted... because of flagrant abuses of power."10

9 Hogan to Buchanan, October 4, 1845, Special Agents Series, XIII, MS. Dept. of State, quoted in Tansin, op.cit., p. 126.

10 Davia D. Porter, Journal of a Mission to Santo Domingo, 1846, quoted in Tansill, op.CIt., p. 128. 
with the outbreak of the Mexican War in May, 1846, the United States pald scant attention until 1849 to the affairs of the Dominican Republic, with the result that the Dominicans, feeling alighted, turned to Europe for succor. By 1849, however, the Dominicans, faced with the threat of being conquered by President Faustin Soulouque of Haiti, once again pleaded with the United States government for a promise of protection or annexation. During this time an American observer described Santo Domingo as a city wheres

Consternation and alarm prevall. The President of Hait1, Soulouque, is within two days' march of this city with 10,000 blacks. He declares extermination to all whites and mulattoes and has beaten the people of this Republic in every battle. My house is already filled with frightened females. - . The Haitian army is almost upon us. Almost all of the foremost merchants have packed up their goods and shipped them to the neighboring lsiands before leaving with their families. The town is filled with women and children from the country and famine is to be apprehended. . . The President has told me that it is his intention to set fire to the place in fase they cannot hold out against the Haitians. II

The American minister, Benjamin Green, while symathetic to Dominican overtures, was forced to remain noncommittal, whereupon, "the Dominican government, on February 22, 1850, addressed identical notes to the representatives of the United States, France, and England, requesting foint inter-

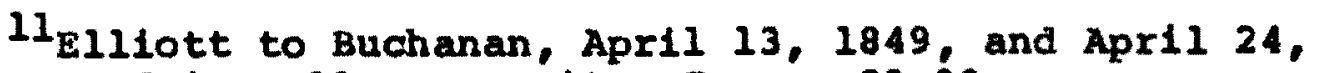
1849, quoted in welles, op.cit.. I, pp. 89-90. 
vention and mediation."12

When Millard Fillmore became President as a regult of President zachary Taylor's sudden death in July 1850, he Imediately appointed Daniel Webster to replace John $M$. Clayton as Secretary of State. Secretary Webster's sympathies were strongly enlisted on the side of the Dominicans and he decided early that "the only effective method for maintalning the stability of the Dominican Government lay 1n foining France and England in a joint mediation."13 Webster's nomination resulted in Robert M. Walsh's elevation as special agent to Santo Domingo and Haitl replacing BenJamin Green. Mr. Walsh set sail for Hispaniola on January 25, 1851 and upon arriving proceeded lmmediately to port au Prince where he presented his credentials to the British and French consuls. In Webster's decision to foln France and Britaln in medation to bring peace to the tiny republic he had instructed Walsh to resist any actions which might "trench upon the just rights of the Dominicans."14 while willing to fointly mediate the Dominican crisis, Washington atill "looked with alsfavor upon European intervention in the

12Tansi11, op.c1t., p. 136. 13 welles, op.clt.. I, p. 112.

14 Webster to Walsh, January 18, 1851, quoted in Welles, op.c1t.. I, p. 113 . 
Western Hemisphere. 15

After presenting his credentials Mr. Walsh informed the Haltian Miniater of Forelgn Affairs that the government of the United states had decided to cooperate with the governments of England and France to secure Dominican sovereignty and that:

Any further prosecution of the war, therefore, 1s abhorrent to the dictates of humanity and reason and injurious to the interests of neutrals. . . The principle is now fully established that the actual possession of independence for a reasonable time entitles a nation to be acknowledged as sovereign. This is a principle which the American world established as consecrated and must ever be upheld . - The best interests of the Haitian Emplre demand the recognition of Dominican Independence.. - In every point of view, therefore, the Government of the United States entertains the conviction that it is incumbent upon the Emperor Domingo.16 to recognize the independence of Santo

Previous to Mr. Walsh's arrival in Port au Prince, the French and British consuls, in conjunction with the Commercial Agent of the United States, had urged Soulouque, who had recently proclaimed himself Emperor Faustin $I$, to accept a definitive peace. When this proposal was turned down the mediating powers suggested a ten year truce. Walsh pushed

15 Graham H. Stuart, Latin America and the United States (4th ed., rev., New York: D. Appleton-Century Company. 1943), p. 278 .

16 Walsh to the Duke de Tiburon, Haltian Minister for Eoreign Affairs, February 7, 1851, quoted in Welles, op.cit.. I. Pp. 116-17. 
the latter 1dea strongly but the responses of the Haitian government remained negative. After four months of fruitless talks "the representatives of the three powers departed empty-handed except for the promise that hostilitles would not be renewed without notification to their governments."17 Dominican President Buenaventura Báez, 18 miffed at the governments of the United States, France, and Britain for their fallure to guarantee protection from Haitian onslaught, In 1858 appealed to Spain to establish a protectorate over her former colony. Spain, however, was not anxious to annex a hornet's nest as "1t feared that assumption of an active role might awaken the jealousy of the United States, and allenate the sympathies of the cuban slaveholders."19 Once again the Dominicans, under a new President, Pedro Santana, looked to the Untted States for protection. On November 2 , 1853 President Franklin Pierce's Secretary of state, William L. Marcy, instructed General William L. Cazneau to proceed as special agent to Santo Domingo. General Camneau, an avowed expansionist, pressed for closer relations between the United states and the Dominican Republic. On the strength of

17 Chester Lloyd Jones, The Caribbean Since 1900 (New York: Prent1ce-Hall, Inc.. 1936), p. 79.

${ }^{18} \mathrm{~B}$ áez was president five times. His terms were as followa: September 24, 1849-February 15, 1853, October 8, 1856-July 7, 1857, December 8, 1865-May 28, 1866 , May 2, 1868-December 31, 1873, December 27, 1876-March 2, 1878. ${ }^{19}$ Jones, op.cit., p. 80. 
Cazneau's assurances that "President Santana's ruling policy is indubitably the creation of the Dominican Republic as an independent American power, preferably under the protection of the United States,"20 coupled with his glowing description of the Republic's natural wealth, the Pierce administration released instructions on July 17, 1854 to Cazneau to negotiate a treaty of friendship, commerce, and navigation, with the stipulation that Article 28 of the proposed treaty was to grant the United States a naval and coaling station at Samaná Bay. 21

Word of the negotiations leaked out, however, and France and Great Britain protested this attempt to secure special privileges of a military character in the Caribbean. When British and French warships, summoned by the two European representatives, Sir Robert Schomburgk and Maxime Raybaud, positioned themselves in Dominican waters Santana and Cazneau became convinced that force might be used to prevent ceding of samana. Cazneau attempted to withdraw the treaty but "schomburgk and Raybaud, in order to ensure defeat of the treaty in the United States Senate prevalled on the Dominican government to insert a clause to the effect that coloured Dominicans travelling in the United States would be

${ }^{20}$ Cazneau to Marcy, January 23,1854 , quoted in Welles, op.c1t., I, p. 144 .

${ }^{21}$ Rayford W. Logan, Halti and the Dominican Republic (New York and Longon: Oxford University Press, 1968), p. 37. 
accorded the same treatment as white Americans."22 Secretary of State Marcy realized such a proposal would meet with early defeat at the hands of Southern Senators and so did not subrit the treaty for ratification.

In 1856 President Santana attempted once again to negotiate a treaty with the United states. The treaty contained only the standard stipulations of friendship and commerce but "rumors that the treaty included a secret convention leasing Samaná Bay to the United States stirred renewed activities by schomburgk and Raybaud . . [and] Santana, realizing that he could no longer look to the United States for support, resigned on May 26, 1856."23 After a succession of chlef executives santana returned from exile to become President for the third time on January 31, 1859. Santana was still convinced that the survival of the DominIcan Republic rested with its being annexed by a foreign power and $s 0$ pressed for negotiations with his last remaining hope, Spain. By March of 1860 arrangements with Spain were nearly complete. Propagandists created sympathy among the people for the idea of Spanish annexation by claiming that Spain had regenerated herself into a modern nation. With ever-increasing enthusiasm it was explained that spain possessed rallways and steamships, encouraged popular education,

$$
\begin{aligned}
& 22 \text { Ibld.. p. } 38 . \\
& 23 \text { Ibld.. p. } 39 .
\end{aligned}
$$


and had repealed oppresaive laws relating to industry and commerce. 24

Spain watched the government of the United States drift toward Civil War and decided that the time was opportune to recapture the glory of a lost colonial possession. On March 18, 1861 the negotiations were made public and Santana addressed a letter to Isabella II, assuring her that,

The Dominican people, giving a free course to those sentiments of affection and loyalty which have been so long repressed, have unanimously and spontaneously proclaimed you as their queen and Soverelgn, and I, who have now the exalted and undeserved honor of being the organ of those sincere sentiments, lay at your Majesty's feet the keys of this lovely island. 25

The Dominicans, however, were not long content under a Spanish hand that dally grew more repressive. Educated Dominicans chaffed under a Spanish administration that replaced local inhabitants in high positions with spaniards. The long awaited economic rejuvenation also was not forthcoming, as tariffs were manipulated to favor Spanish exporters rather than local industry. By 1863 the Spanish army, already thinned by yellow fever, was faced with armed rebel11on. Excesses committed by both sides only fanned the flames of hatred and wrought devastation throughout the land. By 1865 Spain judged the situation as hopeless and plans were

24Tansill, op.c1t., p. 219.

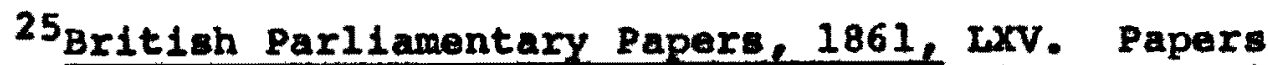
relating to Annexation of Santo Doringo, $p_{0} 28$, quoted in stuart, op.cit., p. 278. 
subaltted to the Span1ah Cortes for evacuation. On May 1 . 1865, Isabella was forced to sign a law revoking the annexation. Once wore the Dowinicans were Independent. After the emanclpation of olaves in the Onited states and the defeat of the Confederacy the tlaklibb problea of recognition of Baitl and the Dominican Republic was at once resolved. Also the faot that spain had entered the caribbean and annexed the Dominican Rapublic "aroused a greater determInation by the United states that the 1sland should never again be dominated by a forelgn power."26 a treaty of friendahip and comerce was concluded with Haitl in 1864 and dipm lomatic reoognition soon followed. Because of the spanish occupancy and the chnotle conditions whlch followed the Domin1can Republic was not recognized unt11 september 17, 1866. In 1866 the question of samaná onee moxe arose. Báez, now in his third term as president, made overtures to seoretary of state seward, who was by now a staunch expansionist. Báex sought money and munitions to keep himself in power, but negotiatione were barely under way when a successful revolt forced him Into exile. Hia succeasor, José Marla Cabral, however, was equally enthused with the prospect of leasing certain keys and coal mines in samana Bay in return for "a illion dollars in the character of a loan on juat, equitable

26J. Lloyd Necham, A Survey of Un1ted states-Latin

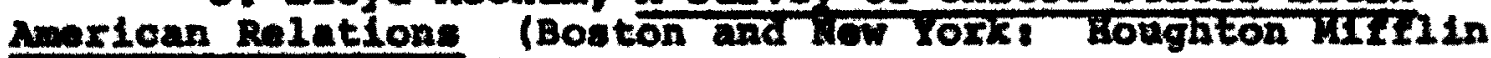
Company, IS65), p. 281. 
and rausonable conditions. - [and a number of pleces of heavy artillery. 027 Cabral also necretly Indicated a willIngness to sedl samand Bay if it would be more profitable to do so. Thle euggention (11ke so many others in Doalnican hletory) was one "made by a hard-preseed government which hoped through the aid requested to consolidate its position. 28 Opposition in the Dominican cabinet, however, based on the conetitutional anendient that forbade trangfer of territory through ale to a forelgn powar, forced Cabral to renage on his prevlous offers.

Although Prenident Cabral sought to renow nogotiations a revolution which erupted in Monte Cristi on October 7 , 1867 forced his adulnistration from power on January 31. 1868 and placed the ever-durable Bás in the president's chalx for the courth time. Bhez' return to power ald not bring to a halt the plans regarding samaná for he "was too sagacious a statesman to fall to recognize the value of American protection." 29

Báex was barely inaugurated when a serles of revolte broke out along the daitian frontlex. In order to maintain his adminletration he showed himself not only villing to aupport a lease convention, but went so far as to press for out-

27Gaxala to seward, November 8, 1866, guoted in Welles, op.c1t.. I. P. 323 .

${ }^{28}$ Jones, gr.elt.. p. 88.

29 otto schounrich, Santo Domingos A Country with a ruture (New York, The Maculitan Company, IS18), p.63. 
right annexation, a policy that had led to his predecessor's ex11e: As his position grew more inaecure Báez becano desperate. Seeking to maintain himself in power he auggested that the Onited states government:

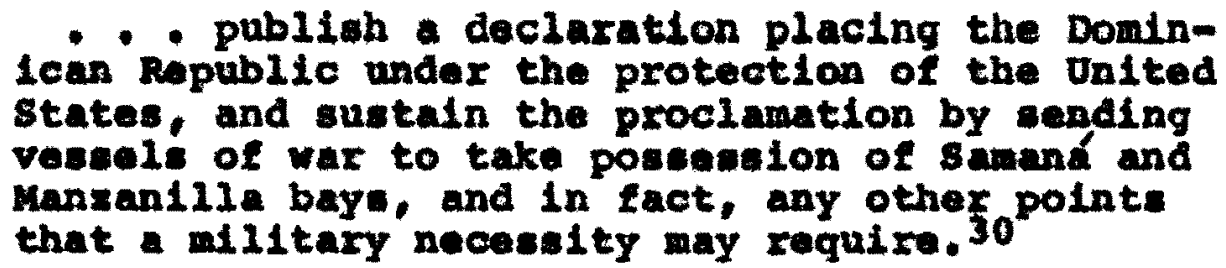

Such a proposal surpased even the flexible measures that

seoretary of state soward had been contemplating and he was

forced in Hovember of 1868 to convey to Báez the following

statoment:

The Congrese of the Onited states Is alwaye disinclined to foreign militury conqueste, parhap more so now than at any time heretofore. It ceams unlikely, thexefore, that congress would entertain any other proposition for the annexation of Dominica than one whioh should originate with and have the sanction of the Dominican people 31

On the Dominican quastion seward had the full sympathy of Prosident Andraw Johnson who stated in his fourth annual masage to Congresa In 1868 that

I an satisfied that the tine has arrived when even so direct a proceeding as a proposition for an annaxation of the two Republics of the island

$30_{\text {Sulth to }}$ seward, October 24, 1868, Santo Doningo, Consular Desp., vol. $y$, Ms. Dept. of State, guoted in Tansin, op.eit.. p. 267.

31 sewaxd to smith, November 17, 1868, quoted in Welles, op. dt.. I, P. 352 . 
of Santo Domingo would not only receive the consent of the people interested but would algg give satisfaction to all other foreign nations. 32

Unhappily for Seward, President Johnson's relations with Congress were so strained that his influence was minimal. Annexationist ambitions in the Caribbean, therefore, lay in abeyance until the advent of the new Grant administration. Under the Grant administration ldeas of expansionism flourlahed as the ex-general of the Union Armies thought that "the imperative need of America was colonial expansIon. 33 Grant took note of the plight of the Negro in the United states and looked to the Dominican Republic as a place where the black man could secure the blessings of "meaningful" liberty. In his memoirs he states that "I took it that the colored people would go there in great numbers, so as to have independent states governed by their own race." 34 with this idea in mind he instructed his Secretary of state, Hamilton Fish, to dispatch General Orville E. Babcock to Santo Domingo to obtain information regarding the conditions of the island

$32 \mathrm{James} D$. Richardson, A Compllation of the Messages and Papers of the Presidents of the United States (20 vols, New York: Bureau of National LIterature, Inc, 1917), XIII, p. 3889 .

33 Tans111, op.c1t. . p. 338 .

${ }^{34}$ Ulysses $S$. Grant, Personal Memoirs of Ulysges $\mathrm{s}$. Grant $(2$ vols, , New York : Charles L. Webster Company, I885). II, p. 550 . 
and the disposition of government and people towards the United states. 35

When Babcock arrived in Santo Domingo in the early summer of 1869 he was immediately collared by william L. Cazneau and his partner in mischief, Colonel Joseph W. Fabers. These two schemers kept the General constantly in their company allowing him to see and hear only the pleasantness of the Republic. Especially did they keep hin away from the resident American commercial agent, J. Somers Smith, who knew the true condition of the island and who frequently "expressed in his communiques to the Secretary of state a sharp suspicIon of General Cazneau and Colonel Fabens." 36

Under the direction of Cazneau, Babcock became intimate with Bhez and was scon a staunch supporter of the ldea of annexation. Upon his return to the United states he urged President Grant to use his influence among members of Congress to popularize the idea of annexation. Grant, easily influenced by his friends, acceded to Babcock's desires. Babcock was then sent back to conclude the negotiations, which were to be signed by Raymond $\mathrm{H}$. Perry, the recent replacement of Commercial agent $J$. Somers Smith, whose only fault had been his unwavering honesty.

Upon his return to Santo Domingo Babcock was once again

35 stuart, op.cit., p. 281 .

36 Tansi11, op.c1t.. p. 372. 
closely supervised by Carneau and Fabens to insure success In negotiations with Báez. His instructions, given to him by Secretary of State Fish, directed $\mathrm{hlm}$, in the event a treaty was concluded, as an officer of the Army of the United States,

states contained in said treaty to protect the peo-
ple of that Republic agalnst forelgn interference
while the nation 18 expressing its will and also
to protect the interest and rights which the United
states may obtain under such convention. 37

In order to help Babcock in this task he was given a draft for $\$ 100,000$ and the backing of the United states Navy if it became necessary to protect the Dominican Republic until the w11l of its people could be ascertained.

On November 29, 1869 negotiations were concluded between the two governments and two treaties were signed, one providing for annexation of the Dominican Republic as a territory of the United States, and the other (in case outright annexation was opposed in the senate) proviaing for the right to lease Samaná Peninsula and 1ts fine harbor within fifty years upon payment of $\$ 2,000,000.38$ As soon as the documents were signed General Babcock turned over $\$ 150,000$ in money and munitions to Báez and, accompanied by Generals Delos B. Sackett and Rufus Ingalls, sailed for Samaná Bay to holst the American flag and take formal possession of the

${ }^{37}$ F1sh to Babcock, September 6, 1869, quoted in Welles, op.cit., I, p. 376 .

${ }^{38}$ stuart, op.cit., p. 281 . 
newly acquired territory.

Báez, feeling his hold on power growing tenuous, appealed to Washington for help, this time with results. By the end of February 1870, seven American warships were stationed in Dominican waters, with orders from the secretary of the Navy. instructing the squadron to direct their operations in accordance with the Indications of President Báez. The influence of Báez, who feared interference from Halti and Dominican revolutionaries based in Haiti, is mirrored in the message sent to President Nissage saget of Haiti by the Commander of the United States Naval detachment. Saget was warned that -any Interference or attack by vessels under the Haitian or any other flag upon the Dominicans during the pendency of negotiations will be consldered an act of hostility to the flag of the United States and will provoke hostility in return." 39

Báez, now safely under the protection of American guns, decided the time was ripe for a plebisclte designed to demonstrate the desire of Dominicans to be united with the United states. Proclaiming the voting booths open in all the provinces, Báez stated on February 19, 1870, that "it is high. time that the Government should take legal steps to assure Itself that the desired purpose is in truth the real expres-

39 poor to Nissage Saget, President of Hait1, February 10,1870 , quoted in Welles, op.clt., I, p. 384. 
sion of the national w111."40 playlng in large part on the old fears of Haitian attack the Government-directed newspaper, the Boletin oficial, assured the people that "Santo Domingo gains everything and loses nothing... Annexation means salvation because it will oblige Haiti to respect Dominican rights and to maintain decent conduct and because it will persuade all Dominicans to renounce political disputes. $=41$

Needless to say, there was no "real expression" of national will. That the voting was not free was evident to al1. Through his police Báez intimidated opponents of annexation with threats of imprisonment and exile. Major Raymond H. Perry, the American Commercial Agent, stated in a communigue to secretary of state Fish that:

Báez has told me several times that if any man opposed annexation he would either shoot him or send him his passports. He also told me that it should be a free vote of the people but such was not the case. . . I have seen Bcez.. . shake his fist in the face of some of his nearest friends - . and tell them he would banish then from the island if they opposed annexation. . . The prisons are filled with political prisoners. 42

When the ballots were flnally counted it was found that out of 16,000 votes cast only eleven were found to express

40presidential decree of Báez issued on February 19 , 1870, quoted in Welles, op.cit.. I, P. 384.

${ }^{41}$ Boletin oficial, Santo Domingo, February 19, 1870, quoted in Welles, op.cIt.. I, p. 385 .

${ }^{42}$ perry to Fish, June 7,1870 , quoted in welles, op. cit., I, p. 386 . 
opposition to annexation. The ever scholarly sumner Welles mentions that these eleven alssenting votes "were recognized as having been cast at the Presldent's instance by his agents In order to prevent the proceedings from appearing too farcical:"43 The results were immediately reported to washington by the Minister of Foreign Affairs who wrote that "the desire is great with which this country almost unanimously is burning to see the conclusion of its annexation to the United States. $=44$

The scene of activity now moves to Washington where the incoming information became a focal point of general discussion. The debate that followed in the senate brought about a serious controversy between President Grant and Senator Charles Sumner, a longtime friend of the president. The President 8 tood for annexation for reasons already stated. Sunner, however, felt the proposed treaty was a travesty of justice, and further felt it would allow the United states to adopt an aggressive policy toward Haiti which his abolitionist principles would not allow. 45 outside the Senate the people of America gave little support to the project and only a few newspapers came to the defense

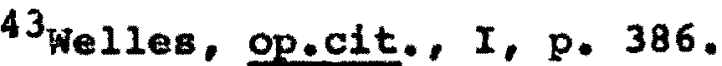

${ }^{44}$ Gautier to Fish, March 18, 1870, quoted in Welles, op.cit.. I, p. 387 .

${ }^{45}$ Jones, op.cit.. p. 94. 
of the proposed annexation, 46 The senate debates were bitter, but sumner, as chaiman of the senate comittee on Forelgn Affalrs, wilelded too much power and influence to be overcome. H1: argwnents were also persuasive, chlef among which are the following:

A. The proposed annexat1on would probably encourage further American acquisitions of Caribbean territory and would thus involve the United states in serlous complications with other powers.

B. There 1: 11ttle 11kelihood of further intervention by Buropaan powers in the affalrs of the Dominican Repubilic.

c. The Undted states, In the event of annexation would probably be saddled with a public debt much larger than had been anticlpated.

D. Continued civil war and rebelilone would be an iftermath of annexation.

B. Annexation would 1mpalr the predominance of the colored race in the west Indies and therefore would be unjust to $1 t .97$

When the vote on Douinican annexation was finally taken on June 30,1870 , the treaty falled by a vote of twenty-ight to twenty-eight, two-thirde being neceserary for ratification. sumner had emerged victorious. President Grant, however. st111 sought to keep the projeat allve and in his second annual maseage to Congress on December 5,1870 , he recommended that:

By Jolnt resolution of the two Houves of Congrese the Bxecutive he authorired to appoint a comiseion

16 rana111, op.c1t.. p. 107.

17 Hew York Herald, March 26, 1870, quoted in Tans111, op.e1t.. P. 406 . 
to negotiate a treaty with the authoritles of

san Domingo for the annexation of that lsiand and

that an appropriation be made to defray the expensea of auch a comalesion. 4

Although Benate opposition to annexation remained strong, tempera oooled enough to allow a proposal to be adopted which would permit three comilestoners to Ingulre once more Into the political and economic condition of the 1sland. Sumner, who belleved our policy should be one of "kindness, benovolence, assistance, ald, help, protection, and all that 1 Implied in good neighborhood," 49 was ult1mately ousted from his comaltee chalmanghip for his dissenting rlewa.

In line with the congressional proposal, President Grant antrusted the fact finding mission to threo distingulshed men: Benfamin F. Wade, Indrow D. White, and Bamuel G. Howe. After an elaborate and palnstaking survey the Inal view of the three Inveatigators was that annexation would be most profitable to the United states. The Grant adninistration, however, scolded dally by opposition editor1als and faced with numerous charges of corruption, was forced to refect furthex proposals almod at annexation of the Dominican Republic. 50

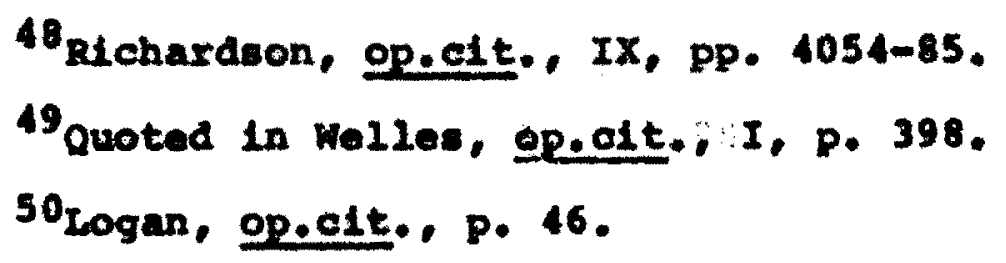


After the 111-favored efforts of Grant and Fieh, the United states lost intereat in further territoxial expanson In the Caribbean region. When, In 1882, President salomon of balti offered to cede the island of La Fortue to the united states, ho was politely refuned. At the time, secretary of state Frederick T. Frelinghuyeen sald that "the policy of this government . . has tended towards avoldance of posessions disconnected from the main continent." 51 In 1884 the overture was extended once more, this time for elther the bay of to nele or the leland of tortuga, and once again the offer was refused. One last fut1le attempt was made to annex samand Bay in 1892, but negotiations were st111 In the Infantile stage when President Benjanin Barricon decided not to go ahead with the plan. 52

Un1ted States" Insistance that the Doninican Republic must never be dominated by forelgn power had led to a pollcy of annexation by Washington leaders who fevored Ondted states expansion In the Caribbean. After the 111faverea efforts of the crant administration, the United states lost interest in any further annexation attempts for a variety of reasons. Chlef among them was a refusal by a wajority of Congressional leadere to embrace the cause of expaneion In the Caribbean. Popular aupport, whlle nover great, dinin-

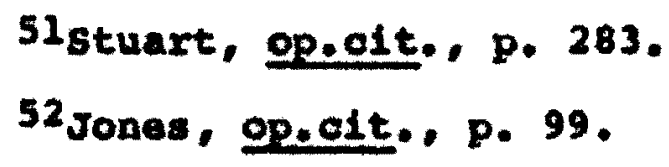


Ished even more with the announcement of the unsavory finanalal operations connected with the project. Indeed in 1892, when Dominican overtures regarding the leasing of samaná Bay were leaked to the press, popular agitation in the United States was so great that President ulises Heureaux was forced to publish an offlclal statement in the Gaceta oflcial denying that any such overture was made. He complalned that:

The great difficulty is your American press. Whenever a Dominican editor writes anything objectionable or puts my plcture in his paper as a carlcature I put him in prison. That settles it. In the United States, the writers abuse their privileges and your ruling men do nothing. That article In the Gaceta oflcial $[$ denial that negotiations were in progreas VII quiet the people. Then Mr. Blaine can send inatructions. We can go to work sow wonths in the future secretly. If we succeed it will be done before anybody can make any nolse. If we obtain no good reault, there will be no bad feeling. 53

Although the United States had lost interest in further attempte at annexation, this "did not indicate by any means any lessening of United States interest in the RepubIics of Hispaniola," 54 for Washington was still insistent that the Dominican Republic must never be dominated by a forelgn power.

53 Durham to General John W. Foster, July 22, 1891 , quoted in Welles, op.c1t.. I, pp. 479-80.

54 Mecham, op.c1t.. p. 281. 
THE CUSTONS RECETVERSHIP

The Dontinican Republic had weathered the turbulence and disorder brought about by Haitian and Spanish intrusion, and by United states" projects which aimed at annexation. By 1900, however, a series of foraign debts, totallng nearly forty million dollars, into which unscrupulous leaders like Buanaventura Báez and olises Heureaux had led the tiny nation, had placed the Dominican Repubilc in a position of debt peonage. Citizens of the United states and of seven European nations became engaged in a confused scramble for the contents of the Dominican treasury. The Dominican Republic was thus menaced with the possibility of forelgn intervention which might lead to inderinite occupation.

By 1904 European creditors vere actively urging their governments to intervene to secure payment on their bonds. Washington, however, was stil1 insistent that no intervantion by a European power in the Western Hemisphere was to be allowed, especially so close to American shores. In order to forestall any action which might lead to European Intervention, President Theodore Roosevelt prowulgated his corollary to the Wonroe Doctrine in whlch he aseerted the right of the United states to act as an International policeman 
In those countries where ahronic wrongdolng or impotence prevented them from meeting their laternational obligations. The following year saw the installment of the Presidant's pollcy on the sumons of Dominican president Carlos I. Morales, who at the time was sorely menaced by domestic and forelgn antagonists. Roosevelt established a custons recelvership designed to control and direct Dominican revenues which he belleved would bring pace to the lsland and satiefy claworing forelgn oreditors. Unfortunately, the long awalted stablilty was not forthooming and the plan that was admirable in its qualities becane but the first of a series of steps that led to outright military intervention in 1916.

The year 1869 witnessed the genesis of the Dominican debt when Beenaventura Báez, confronted with depreclated currency and threatening revolutionaries, negotlated an advance of $\$ 757,700$ from a group of English bankers headed by Hartmont Co. The loan was typlcal of the exorbltant discount rates whlch poor and unstuble countrles had to pay. sumer Welles coments that "the terms were of so onerous a character as to be almost incredible. $\$ 55$

I. Einally agreed upon, the Loan was reduced to E420,000 by the Dominican senate of which E,100,000 was earmarked as a comalsion for Hartmont c Co, For the remaining E320,000

55 We11es, op.e1t.. I, p. 359. 
the Doninican government pledged itself to pay $\mathbf{5 8 , 9 0 0}$

annually for twenty-four years, a sum amounting to wore than four tiwes the face value of the loan. As security, the Dominican government pledged the entire resources of the Republic--spec1f1cally, the customs revenue and the revenues Exom guano, coal, mahogany and other forest products. hartmont Co, sold bonds amounting to $\Varangle 757,700$ to the public at rates rangling from 50 to 70 per cent, but by reason of neglect, fraud, or deliberate defalcation, only $\mathbf{H}_{38,095}$ was recelved and ccounted for by the Dominican governient. 56 Báes and the Dominlcan senate, realizing they were belng nercilesely fleeced, canceled the oontract in 1870 . Interest on outstanding bonds was pald unt1l Auguat 1872, when the low went into default. The boxrowed woney was intended to promote rouds and rallways, but instead was used to ozumh Baes" opponents and Iine the pockets of his supporters. Further default under following adminlstxations nat increasing objection Irom the British government, which in retrospect augured poorly for the future.

Between 1872 and 1888 the story of the Dominican dabt 1s one of ateady accumulation of floating indebtadness. salarles of clvil eervants were left unpaid, clalms for Injuries suffered in the many revolutions were freely extendad,

56 Jacob H. Bollander, The Readjustment of San Donincol Finances, guartexly Journal of Boononice, XXI. (May, 1907). p. 405. 
treaeury b111s were printed for the purchase of war mater1al. and funds for ourrent expanditure were borrowed from money lenders whose greed knew no bounds. The Hartmont flesco had, for the time being, discouraged further bond issues, whlch placed the Dowintean government at the morcy of the werchant lenders of the Republic whose interest rates were not inirequently as high as 10 per cent a month, compounded monthly. By 1888 the total bonded debt of the Repub116 had risen to $\$ 3,850,000,57$

The last fifth of the nineteenth century was the period of another diatatox, UI1ses Heureaux, who becane President on september 1, 1882. Apparently of 111egltimate birth, Heureaux obtained the practical education of a soldier in the 11eld. Fearless, oruel, sensual, and a leader of men, he dominated Dominican affalre until an assaseln's bullet ended his tyranny in 1899. Of his adminletration, Profesenox Chester Lloyd Jones states that:

Boureaux' rule was to be one in which the Bepublic alld oteadily from a bad to a woree position and oue in ihloh there developed abuses which made the Dominlcan Rapublic in the early years of the timentleth cantury the center of far-reuching international conlications threatening the continued exiltence of the nution. 58

Just an Presldent Báez had done In 1869, so d1d Pres1dent Heureaux in 1888, embarraseed by an empty traesury and

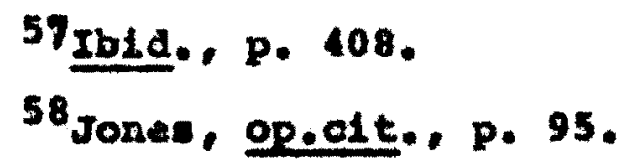


harassed by dometic and forelgn creditors, turn to the forelga money warkets as a solution for the Rapublic'a Lnanclal 1118. A oontract was entered Into with Westendorp C Co.. of Amsterdan which provided for the lenue of 1770,000 thirty-year 6 per cent gold bonds. To placate British bankers and the orttiah government; the sum of E/4,860 was to be used to IIquidate the Hartwont loan. Since the Dorinican government had recelved only about $\$ 150,000$ from Hartwont, It found Iteelf paying back 6,1 for $\$ 1$ when at the tiwe the pound was worth $\$ 4.80 .59$ The amall oum of 150,000 was earmaxked to pay off the Interior floating debt whlle Weatendorp 60 . bought the remainder of the bonds at 78 per cent of thelr face value, For security, westendorp c Co, was given a frebh Ilen on cuetome revenues, which were to be collected through a board of agents, the régle, who were to collect the amount necessary to sexvice the loan charges and pay for collection expenses. The remaining revenue was to be turnad over to the Dominican government.

In 1890 a second loan in the sum of 2900,000 , redeanable in fifty-six years at the rate of 6 per cent, was negotiated with heatendorp co., to becure fund for the construction of a railroad from puerto plata to santiago. Unhappily for Dominicans, Heuxeaux uned most of the money to Ild himeelf of frosh accumulations of loating lndebted-

${ }^{59}$ Logan, gr.e1t.. p. 50. 
ness and squandered the rest on personal extravagances. In the meantime, Westendorp \& Co. enoountered government interfexence in the collection of customs duties. When Heureaux desired funds he would seize certain revenues and pledge them to local merchants to obtain whatever he needed.60 As a result, the régle was unable to service the bonds. When Eeureaux defaulted on the two Westendorp loans In 1892 the Ansterdam banking firm applied to two New York attorneys to negotiate sale of the bonds to the United states government. Washington flatly refused the offer, but Secretary of state roster suggested that an American firm take over the dut1es of Westendorp to forestall any tranefer of Interests to French or German bankers. 61 Immediately the comalssioned attorneys, smith M. Weed and Charles W. Welles, organlzed the San Domingo Improvement Company of Wew York and acquired the rights and obligations of westendorp $C O$. By 1893 the San Domlingo Improvement Co. had become the Douintcan Repub11c's banker.

Fresh money was essential if Heureaux was to maintaln his despotic control. The tyrant secured it in the form of two loans exom the San Domingo Improvement Co. stifch agreed to extend a total of $\$ 3,285,000$ to refund old obligations

60 gohoenrlch, Qp.c1t.. PP. 355-56.

61 Dana G. Munro, Intervention and Dollar Diplomacy in the Carlbbean 1900-1922 trew Jersey: Princeton oniversity Prese, 1967). p.80. 
and to meot new debte. The fifth, sixth, and seventh loans, totaling $\$ 4,250,000$ were extended in 1893-95 for the purpose of discharging floating debts and quieting indemnity clatme.62 Although not always harmonious, the working relations between Heureaux ano the $\mathrm{San}$ Doringo Improvement Co, were close. When, In 1895, France threatened to seize the Dominican custom houses because of the dictator's treatment of the French owned national bank, the san Domingo Improvement Co, came to his aseistance and undertook to pay off the indeanity which France required and later bought the stock of the bank and operated 1t as itg own property. In 1897, when the Dominican government once again defaulted on the payments of its foreign debt, the company carried through anotber refunding operation and undertook to float an elghth bond issue of $2,2,736,750 \mathrm{in}$ bonds at $23 / 4$ per cent and $\mathrm{E}, 5,500,000$ in bonds at 4 per cent. The lasue was designed to convert all previous bonds then outstanding and pay overdue interest while supplying the Dominican government with $\$ 1,000,000$ in cash. 63

The San Domingo Improvement Co., however, was not able to carry out the contract to its fullest extent because of - lack of funds. Bventually the conversion of older bond 1seues was complated, but at enormous cost. Professor Jacob

${ }^{62}$ Hollander, op.c1t., p. 410.

63 schoenrich, op.cit.. p. 357. 
H. Hollandex reports of the transaction as one whichs

- - involved cut-throat terms, and unchecked procedure. Instead of the conomical and orderly readjustment that was to put the financlal household of santo Domingo in order to re-establish her public credit, there resulted a swollen deblt, loose in construction, sugpiclous in detall, and foredoomed to break down.

During Heureaux' adminlstration the San Domingo Improvement Co. paid the Dominican government from 30 to 43 per cent of the face value of the securities and in the main sold the bonds not to Arericans, but to Europeans, mostly in Belgium and France. Deception of every type was practiced by the bond seliers as evidenced by the fact that a large number of the French holders of Dominican bonds were poor Catholic peasants in France who were told that they were buylng securities of the Dominican religlous oxder. 65 other investore were attracted by the supposed security afforded by the company's right to collect customs dutles and the guarantee written Into each loan contraot that the company could ask the Dutch, Belgtan, British, French, and United states governments to appoint a board of comiseloners to collect customs in case of default.

The guarantees proved 111usory, however, as the collection agents, who were Dominlcans, practlced every type of fraud, which served only to reduce customs revenues to a

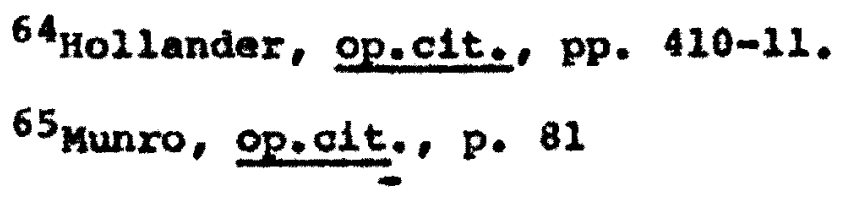


trickle. Needless to say, though successive defaults occurred, no 1 ve power government board was set up to insure payment on the loans, partly because the varlous governments differed over the roles they would play, and partly because the san Domingo Improvement $C o$. felt they could always find more gullible investors to line their pockets with silver. By the turn of the century, however, it proved nearly impossible to sell any sizeable number of bonds, and the Repub11c was again in default when Heureaux was assassinated in July of 1899.

It was folt that Heureaux' passing might usher in a period of responsible government, but the huge forelgn debt that saddled the Republic, coupled with the inablitty of political leaders to reconcile their differences, dashed all such hopes. In flnanclal matters the worst features of Heureaux' adrinivtration vere Intensified. Each successive President, harxled by political rivals, becane more reckless borrower, and each new loan was obtained upon harsher terms. Professor Hollander reports that "the noalnal rate of interest upon public loans was rarely less than 2 per cent per month, and, with respect to funds or values actually received, several times that rate."66 Professor Hollander goes on to state that on the eve of the establishment of the Customs Recaivershtp by the United states In

66 Hollander, op.c1t.. p. 411. 
1905 that santo Domingo was found to bes

- - a contessed bankrupt, whone public faith was discredited no las at howe than in every financial market of the world, whose current dobits were havked about as ilttle better than waste paper, whose people were cruehed under a galling buxden of taxation, whose natural resources were mortgaged In extravagant or send-fraudulent concessions, whose legltiwate oreditors were left without compensation or redress, and whose political existenoe was threatened by contractual obligations and international agfeements in the interest of forelgn creditors.

The position occupled by the $\operatorname{san}$ Domingo Improvesent co. was unsatiefactory to all Involved parties. The company wished to terminate its responolbilities and the Dominican govermment, headed now by Juan Ialdro Jimánea, worely wanted to apeed ite withdraval as the company was thoroughly hated by Donlnicans because of its long aspoclation with Heureaux. 68 The problem was flnding security whioh would allow the company to withdraw without jeopardining the intereste of lts omexs.

In epite of hostile public oplnion, President Jinónez In March of 1900 endorsed a plen which would have allowed the company to continue customs collections in return for financlal concessions. Frenoin and Belgian bondholders, however, refused to agree to further concessions and the Belgtan government notifled the Dominican government that the company

67 Ibld.. p.412.

68mivin M. Inight, The Anericans in sento Dowingo (How Yoxk: vangumed prese, ISzU), P. 15. 
no longer represented Its national's interest. Jimbnes, disgusted over his proposal being rejected, terminated the San Domingo Improvement Co." right to collect customs, although he set up a comisalon to withhold 16 per cent of the custom recefpte to insure payment to the bondholders. What followed was Inancial confusion. Governments began to act Independently of the San Domingo Improvement $C O$. and in support of their own eltizens, and a confused scramble sce the contents of the Dominican treasury eneued.

In seeking a solution, President Jimbnez entrusted his Minleter of Forelgn Affalrs with the task of making separate arrangenents with the French and Belgian bonaholders and with the Improvement $C o$. The negotiatlons proved successful, but when the Dowintcen Congress approved the agreewant with the Buropean bondholdere and not with the Improvement Co., new aompllaations arose.

To this point, the United states state Department had lent little support to the Improvement co.'s plight, their only suggestion beling that the Dominican Republic buy out the hated coapany. The obstacle encountered here. of conree, was Dominican opposition and the lack of tunda to carry through such an agreament. 69 with the agreement that gave the rrenoh and Belglan bondholders a lien on the customs of santo Doningo and san Padro de Macor1s, however,

${ }^{69}$ Ibla. 
the State Department deoided that American Interests ware not golng to be elmply dismlesed. Secretary of state John Hay, disturbed over what he termed "discrimination against Amerioan companies" Informed the Legation at Santo Domingo to Inform the Dominicans that the American government was "not disposed to pass over unheeded the equities of the American compenies" and that if all othex methode of attempted settlement called, the Domlnican government should allow arbitration. 70

secretary Hay probably aid not intend that the Legation vigorously support the Improvement Co.'s claim, but Will1am F. Powell, Minister to Haitl, who carried out Hay's Instructions In santo Domingo, addressed note to the Dominican governmont that demanded, in no uncertain terms, a settlement sat1sfactory to the $\operatorname{san}$ Domingo Improvement $\mathrm{Co}, 71$ The state Departiont reprimanded him for his overzealousness and his fallure to mako olear that the state Department was werely offering 1 ta good offices to affect a settlament. In epite of this reprimand, however, Powell was Instrueted to proceed with his efforts to persuade the Dominioan govornment to enter into constructive negotiations with the Improvement Co.

Hegotiations in 1901 came to nothing and were inter-

$70_{\text {Hay to }}$ Powel1, January 20, 1902, quoted in Munro, op.cit.. p. 83.

71 powell to Hay, February 22, 1902, quoted In Munro, op.cit.. PR. 83-4. 
rupted in 1902 when a ravolution ousted Jimánez and placed Horaclo vásquez in the President's chair. When discusstons were once more interred into, the Improvement Co. stalemated progress with its refusal to subult its financial accounts for governmental inspection after it had agreed to accept $\$ 4,500,000$ instead of the original $\$ 11,000,000$ it had demanded. The Btate Department suggeated the whole question be settled by arbltration but altexed 1ts position to urge arbitration on only how the sum should be pald. 72 After much polltical blekering a protocol was igned on January 31, 1903, whereby the Dominican government agreed to pay the United states government, for the san Domingo Improvesent Co., the sum of $\$ 4,500,000$ in gold. The mannar In which the money was to be pald and the conditions under which the Improvement Co. would relinquish its properties were to be ascertained by arbitration between the two govarnments. This brought about the and of private receivership and forelgn oreditors were now justified in looking to their governments for collection of debts.

The Dominican government, under President vásquex, went ahead with plans to select an arbitral commission, but a succession of revolutionary uprisings succeeded in placing General wos y Gil, a onetime lleutenant of Heureaux' In the Presldent's chalr, who was opposed to the newly signed

72 Munro, op.c1t. , p. 85. 
protocol. It was not unt1l December that the arb1tral comisaton finally wet. In 1ts final deciation the board fixed the interest rate at 4 per cent and stated that the monthly payments were to be $\$ 37,500$ a month for two years, and $\$ 41,666$ month thereafter. In case of fallure to pay from customs revenues secured on the northern coust, a financlal agent of the Onited states was to take over the Puerto plata customhouse and carry out the agreement. 73 Unfortunately for Dominicans, a nev serles of revolutionary outbreaks occurred which disrupted the country and placed a new miltary leader, Carlos Morales, at the head of the government. In the face of such chaos, it was impossible for the Dominloan government to make any payments on the forelgn debts and, In compliance with the terms of the July award, an American financlal agent took over the oustomhouse of Puerto Plata on October 21, 1904. In November Morales established himself as president, but clvil atrife continued unabated as the supporters of former Presldent Jiménez continued to ravage the countryside. In the face of such utter breakdown in orderly government, the French, following the American example, threatened to take over the Santo Domingo customhouse, an action whlch would have paralyred the government for lack of funds.

73 papers Relating to Forelgn Relations of the United

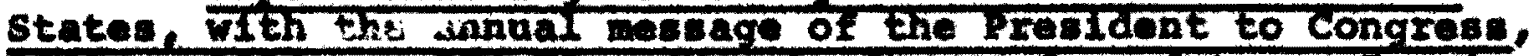
1861-1 1904, pp.274-79. HereInafter referred to as porelgn Terations. 
In 1ts relations with the Dominican Republic in 19021903 the state Department concerned 1tself primarily with settlement of American claims by insisting on arbitration, a normal part of its work. Roosevelt and hay gave no indication that either wished to obtain control of the Republic's internal operations. Indeed, at a later date, Roosevelt stated that he thought the pressing of the San Domingo Improvement $C 0$.' claim had been a mistake which a critically 111 Hay would not have allowed if he had been a well $\operatorname{man} .74$

In the first months of 1904, however, Roosevelt's attitude changed as he began to see the need for policies which would prevent further incidents like the venezuela blockade of 1902. In Roosevelt's opinion, the Latin American nation most susceptible to European intervention was the Dominican Republic. With alarm he noted that rivalries between creditor powers had placed the Dominican government In a most unfortunate position and that numerous revolutionary outbreaks had, in April of 1903, prompted a German warship to land 150 men to protect the German consulate. ItalIan and Dutch ships also entered the harbor. 75 He also knew that complete anarchy had engulfed the nation in the Fall and American, French, Italian, Dutch, and German vessels

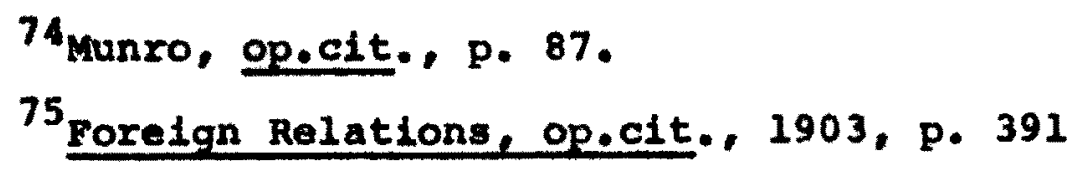


had landed milltary personnel to protect thelr respective forelgn Interests. 76 In a letter to J.B. Bishop, dated February 23, 1904, Roosevelt expressed hls attitude, statings

I have been hopling and prayling for three months that the santo Domingans would behave so that I would not have to act in any way. I want to do nothing but what a pollcenan has to do in santo Domingo. As for annexing the 1sland, I have about the same desire to annex it as a gorged boa constrictor might have to swallow a porcuplne wrongond-to. If I poselbly can, I want to do nothing to them. If it is absolutely necessary to do sqmething, then I want to do as ilttle as possible. 77

Roosevelt proceeded cautiously, however, as 1904 was an election year. In May, at a banquet comenorating the second anniversary of the independence of cuba, bellon d' easal was released. In a seech read by Elihu Root, he declared that the principle desire of the united states was to see all neighboring countries stable, orderly and prosperous," and elaborated further that if a nation demonatrates that,

- It knows how to act with decency in Induetrial and political matters, if it keops order and paye ite obligationa, then it need fear no interference from the United states. Brutal wrongdoing, or an impotence which results in general loosening of the ties of civilized soclety, way finally require Intervention by some civilized nation, and

${ }^{76}$ Tullo Manuel Cestero, Eutados Unidos y las Ant11las (Madrid, 1931), quoted in Jones, Op.c1E.. P. 103.

77 Joseph Bucklin Blahop, Theodore Roosevelt and His Time shown in His own lettere $(2$ vols.) ken York Charles scribner' 50ne, 1919,1920), I, p. 431. 
in the Hestarn Hemisphere the onited States cannot Ignoxe this duty.78

After a decisfve victory at the polls in November, Roosevelt, "convinced of the dangers inherent in the polley of negation and mediation," "which he had pursued in the venezuelan cxileis. "embarked upon a course of positive action in the Dominican Republic in line with his own character."79 With encouragement from the Morales government, which had, for some time, desperately appealed for ald, Roosevelt restated his pronouncement of May the $20 \mathrm{th}$ in his annual message to Congress on December 6, 1904, spectflcally declaxing that:

Chronic wrong-doling, or an impotence which results in general ioosening of the ties of civilized society, may In Amerioa, as elsewhere, ultimately require intervention by some cipillzed nation, and in the Hestern Howlsphere the adherence of the Onited states to the Monroe Doctrine may force the United states, however reluctantly, in flagrant cases of such wrongdoing or impotence, to the exerciae of an international pollce power. 80

Following Roosevelt's address, Hay cabled the American Minister, Thome C. Dawson, on December 30, 1904 and directed

78H. Pringle, Theodore Roosevelt (New York, 1931), quoted in Dexter Perkins, A HIstory of the Monron Doctrine (Boston: Lfttle, Brown and company, 1955), pp. 238-39.

79 Howard C. HI11, Ph.D., Roosevelt and the Carlbbean (Ililnois, Univeraity of Chicago Press, 1927), p. 148.

${ }^{80}$ House Document Yo. $_{1}$ (P1fty-eIghth Congress, third session), quoted in iIII. Op.01t.. p. 149. 
h1m to:

sound the President of santo Doningo discreetly but earnestly and in perfectly friendly spirit, touching the alsquileting st tuation which is deveioping owing to the preseure of other governments having arbitral awarde in thair favor and wo regard our award a conflicting with their rights. - You will ascertain whether the covernment of Banto Doningo would be almposed to reguest the United states to take charge of the collection of dutles and effect an equitable distribution of the aselgned quotas anong the Dominican Government and the everal clalmants.81

To aid Daweon in negotiating a plan that would allow American representatives to administer customs collection, Roosevelt arranged for Cosmander Albert C. D1llingham, a naval officer possessing wide knowledge of the laland, to assiat the Minister in any way he could.

On January 20 an agreement known as the D1llinghamSánchez protocol was eigned, providing for a guaranty by the United states government of Dominican territorial Integrity and for control of all Dominican customhouses by the Onited states. Dabate over certain detalls, such so the clause guaranteelng Dominican terxitorial integrity, delayed the completion of negotiations until February 7, 1905, when a now protocol was eigned which stipulated that the United States should turn over to the Dominican government 45 per cent of all customs revenue while using the remaining 55 per cent to service the Republic's forelgn and domestio debt.

81 House Dooument No, 1 (Elfty-ninth Congress, firet seseion). quoted in HII, op.oit.. pp. 158-59. 
It wae also agreed that the Unlted States would grant the Republic assistance in restoring the credit, preserving the order, and fostering material progress for the welfare of her eltizene. 82

In subintting the protocol to the senate on rebruary 15, 2805, President Roosevelt urged 1ts acceptance, saying that the Un1ted states government could:
- . not with propriety say that $1 t$ wi12 pro- tect 1 ts own citizens and interests on the one hand, and yet on the other hand refuse to allow other governments to protect their citizens and interests. - . [and cautioned that those who profit by the Honxoe Doctrine must accept certain reaponsiblities along with the rights which it conters.83

Encountering opposition within the senate, even though the Senate Porelgn Relation Committee recommended approval, Roosevelt, in a special maseage of March 6, 1905, stresned the point that:

Santo Domingo grievously needs the ald of a powerful and fxlendly nation.. She has asked for this ald, and the expressions of friendship repeatedly sanctioned by the people and covernment of the Onlted states warrant hor in belleving that it w112 not be withheld in the hour of her

In an attempt to rally amerioan oplnion behind the treaty In a speech given at the Chautaugua in New York, he appealed, in the worde of Professor J. Fred Rippy, "to the

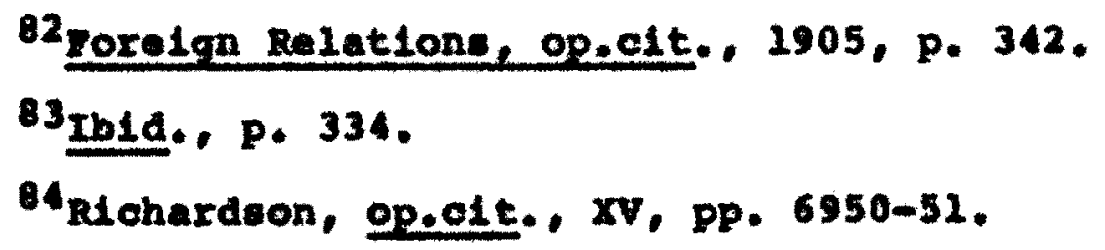


mind and sentinents of the average man," and stated forthrightly that:

We cannot parmanentiy adhere to the Monroe Doctrine unless wo uceeed in waking it evident in the firet place that wo do not intend to treat 1t . . as an excuse for aggrandizement on our part at the expence of the republics to the south of ue, eecond, that wa do not intend to permit it to be used by any of these republios as ahield to protect that republic from the consequences of lts own wisdeeds agalnst forelgn nations, thixd, that Inasmuch as by thi doctrine we prevent other nations from interfexing on this side of the vater. we shall ourselves in good salth try to help those of our siater republles, which need such help. upward toward pence and order. 85

Roosevelt's exhortations falled to convince the senators, however, as they "wore unmoved by benevolence, tear of European Intervantion, concern for vasted interests, or expansioniat lapulses.86 seeing that the two-thirds majorIty needed for approval could not be obtained, Roosevelt allowed the watter to be set aside unt1l the senate opened 1te regular seselons in December. When, on March 18, the United states senate adjourned without acting on the protocol, rumors of revolution spread throughout the capital and forelgn creditors renewed thelr demands for payment of claims. To worsen the situation, an Italian cruiser anohored in santo Domingo': harbor to lend support for Itallan clains. A new crisls had arisen.

85 Wew York TLimed, August 12, 1905, quoted in J. Fred Rippy, The Initiation of the Custome Recelvership in the Domini can Repubile," HIepanic Agerloan Historic Review. XVII (Hovenber, 1937), p. TS5

$$
{ }^{86} \text { Rippy. Qp.c1t.. p. } 456 .
$$


In the face of Impending disastex, the Doninican Min1ater of Finance Informed Daweon that he could continue in his position only if a practioal modus ilvendi was adopted, pending ratiflcation of the treaty. 87 Dawnon sounded out the claimants, and finding only the Improvement co. unreceptive, cabled the Doninican proposal to Washington. Roosevelt approved the proposed arrangenent, but made it elear that all posts would be afeceted, which mant that the Improvenont Co. would lose its control of the northern ountomhouses. of the monay collected, 15 per cent vas earmarked for the DomInloan governmont while 55 per cent was to be placed in a Now rork benk until the senute ratifled the treaty, in which case it would then be distributed awong the claimants in proportion to thelr claima.

Doosevelt's proposals were accepted and the Morales' government slgned Into effect the Receivershlp on March 31, 1905. Within few weeks noosevelt nominated, and Morales appointed, Colonel George R. Colton, a long-tima custome collector in the Phllippine Ialands, as Ceneral Recelver and Collector. Speaking later before the Senate, Roosevelt justifled the receivership by saying that:

\footnotetext{
- Itabllity and order and all the baneflts of peace are at last conlng to santo Domingo, danger of forelgn intervention has been euspended, and
}

$$
\text { 87日111, 오.c1t., p. } 161 .
$$


there is at last 8 prospect that all creditors
w11 get fustioe. 88 .

Roosevalt's actions touched off a torrent of abuse against him in the senate. Following the lead of senator Morgan of Alabama, who had served on the Comalttee on For- Ign Relatioh alnce 1879, Senate exities denounoed his cause as unconstitutional; saying that he had "put into execution a treaty which the senate had refused to approve and that he had establiahed a protectorate over santo Domingo." 89 The modue rlvendl, however, entabllahed elnanclal oxder and the Dominican government recelved more from 1 ts 45 per cent share than it had from a previous 200 per cent, further, the amertcan Recelver ceneral, Colonel colton, noted that during 1ts twanty-aight months of operation, "not one single complaint nor line of eriticisa was recolved from the Dominicen Covernment, nor from any consul or apeclal representative."90

The resounding success of the modue rivendt alded roosevelt in securing approval by the senate, and the executive agreenent was replaced by a formal treaty which went into effect on July 8, 1907. The treaty contalned the principal Eeatures of the 1905 agreement, ondtted, howerer, was the agreowent of the United states to respect the territorial Integrity of the Dominican Republio (1n deference to senator

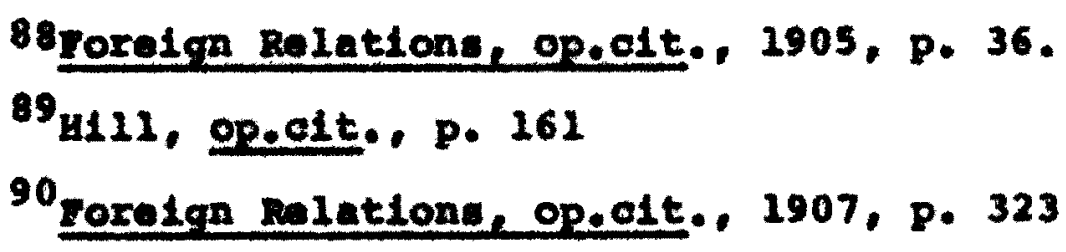


wo lelt there was little difference between respecting and guaranteeling antion's territorial (ntegrity), and the clause which pledged assiatance by the united states for the purpose of preserving order, which was objected to on grounds that "the provision would Involve the United states In the Internal affairs of santo Domingo." 91 It was also agreed that the Dominloan government would not increase it: publ1e debt except by previoue agreement with the onited states unt1l the eull amount of 1 te forelgn obligations had been pald. 92

By 2904 Elnanclal miswanagoment had brought the Donin1can Republlo periloualy close to European intervention. In an effort to stave off such a threat, whloh mlght have led to Indefindte occupation close to Amerloan shores, Washington found herself once more deeply involved in Dominlcan affalrs. President Roosevelt, with the promulgation of his Corollaxy to the wonxoe Doctrine, woved gutakly to establish a Custome Recelvership, which satisfied the clanoring foreign creditors and arased the threat of forelgn intervention.

It was belleved that such an arrangenent would also bring pace to the 1sland, but recurring disorders whin the island Republ1c demonetrated the wakness of such hope.

\footnotetext{
91:111, ㅇ․c1t., P. 167.

92 Porelgn Relations, op.c1t., 1907, pp. 307-09.
} 
In an attempt to end the reourring cycle of insurrections In the Dominlcan Republic the W1lson Administration broadened United 8tates involvenent, and Roosevelt's plan, which was so admirable in 1 ts qualities, became but the first of a serles of step: that led ultimately to allitary occupation in 1916. 


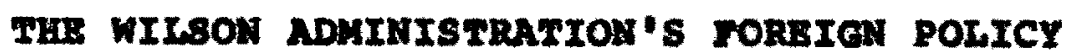

IN THE DOUINICAR REPUBLIC

Since the Dominican Republic's Incoption as an Independent nation in 1844, United states forelgn policy had centered around the ldea that the tiny 1sland Republic must nover be dominated by a forelgn power. To forestall forelgn Inoursion, this policy had led to attompte at annexation in the nineteenth century and to the establishment of a customs recelverahip in 1905. While the Wilson adminietration adhered to the established pollcy in reapect to forelgn Inoursion, Presleant W1Ison brosdened Onited states Involvement in the affalxs of the Republic by lnalsting on the astablichwont of a conatitutional democracy which, in his mind, was neceseary to put an and to the recurxing oydes of revolution. When it became evident that political and Inancial tabllity were not to be so easily obtalnod, w11son reluctantly ordered the Republic occupled by the Marines, who were then to Instruct the Dominicans in the waye of democracy.

In the years Immodiately following ita establiahment, the customs recelvershlp astablished by Roosevelt wad a financlal succese. Speaking of the advantages gained, the 
Dominican Minlater of Finance, Federico Velámquez, in his

annual report for 1906, stated that:

\begin{abstract}
The 1tems of revenue during 1905 and those of 1906 epeak clearly, with renewed eloguence, of flgures, that for sone time past we have been 11ving in the public posts a life of order and honesty, where but a few years ago ilfe with few exceptions within and without the national palace was one of shameleseness, dilapidation, cupialty, and permanent alegrace for the Republic, beling the princlpal cauee, If not the only one, why our weak tate has felt 1teelf wore than once trembiling on the brink of the abyes, and that for a long time we have found ourselves lacking in economic autonoay, overwelghed by dobte, unjusti1lable for the greater part, oufferlng insuite and humilities. 93
\end{abstract}

Uninterrupted parce did not follow, but the American Miniater Thomas C. Daweon reported to state Department officials that revolutionary plotting had abated becanse of the Inabil1ty of revolutionaries to plunder the collection poets. He also reported that agriculture and cattle raleing were again flourlaning and that, for the firet time, public officiale were recelving their salaries on schedule. 94

Under Ramb́n Cáceres (President 1906-1911), relations with the United states were harmonlous. Cáceres inspired. truet in his administration by appointing ablo wen and insisting on honesty in government. It was because of this, in part, that his presidenoy was one of the freest, most peaceful, and conetructive in the Republic's history. But

93 rorelgn Relatlons, op.c1t., 1907, p. 357.

94 Ibld.. 1905, p. 379. 
at a time when the future eoened brightest, Dondolcans wore startled by the newr of Caceres' aseaseinntion on November 19. 1911. The country then fell into the hands of ceneral Alredo $N$. Victorta, comander of the Republic' ailitary. Being only twenty-a1x years old, he was not of constitutional age to be President, but intrigued to secure the election of his uncle, Eladio Victorla. The government was quickly converted into a stark wlltary dictatorship and number of leading political and military leadere raised the standard of revolt and ocoupled parts of the nation from which they refused to be dislodged. In Wahington the disruption cast wore than a little doubt upon the Infallibility of the Rooseveltian prescription for malntaining the peace of the Caribbeen, and raised the question of whether the more control of custams was a concluslve remedy for donestic alsoxder. .95

Washington at firet supported the de facto regine, warning the revolutionists that it was the practice of the Onited states "to refune to recognise any government reaultIng from revolution unlese it appeara to represent the w11l of the people. 96 Revolutionary opposition, however, was too formlable for wanhington to overlook, and when it beoam apparent atter montho of lighting that the struggle

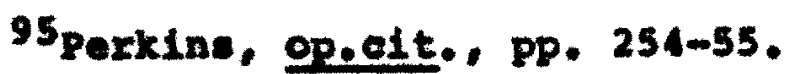

96 rorelon selatione, op.c1t.. 1912, pp. 341-12. 
was a deadlock, the United states government offered 1ts good offlces with a vlew of re-establishing peace and order in the troubled Republ1c. 97

Acting on the recomendations of the American Minister to Santo Domingo, W1211am W. Russell, who was upset by the closure of interior customhouses by the fighting, 98 a apecial comiseion appointed by president raft, consisting of General Frank McIntyre of the Burean of Insular Affairs of the War Department and Mr. W.T. Doyle, Chief of the Latin American Division of the State Department, arrived in santo Domingo on October 2 to investigate the existing situation. They were also acoompanied by 750 Marines, whose duty 1 t was to protect the customhouses, if it became necessary to do so.

Upon their arrival in santo Domingo, the Combsioners advised the President, Eladio Victoria, to declare general annesty and renove immediately his nephew, General Alfredo Victoria, from his dutles as minister of war and Interior, and to co-operate promptly with the American Minister Russell in re-entablishing to working order the interior custoahouses, and Inally, "to make all other reforms needful for the protection of revenues and the restoration of

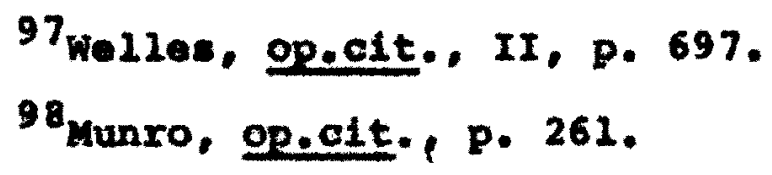


quitet and content throughout the Republic."99 At first, vlotoria seemed willing to aseent to the "suggestions" of the Comalsatoners, but later proved recaloitrant. In the face of Victoria's stubbornness, "the response of the United states was that in view of misuse of funds in the past, Instructions would be given to the Ceneral Recelver of Dominican Castom to cease all payments to the established govermment. 100 In the same vein, no revenues were to be given to the rebels and any govarnment established by them would not be recognized. Left virtually pennilese, Victoria resigned on November 26, 1912 and the Domlnioan Congress settled dom to electing a candidate acceptable to the warring eactions.

On Novamber 30, 1912 the Domintean Congress elected the portly Adolfo Nouel, Archbishop of Santo Domingo, as provisional president. The choloe of the amiable Nouel brought an immediate cassion of hostilities and the Amerloan Comalseloners, accompanied by the 750 Marines, left for the United states with the situation apparently in hand. The good Archblshop, however, was not of forceful character, and after foux monthe he retired to Europe complaining of 111 health. Friction between political factions continued to

990uoted in welles, gp.c1t.. II, Pp. 695-96.

100 wilfid Hardy Callcott, The Caribbean Pollcy of the on1ted States, $1090-1920$ (BaItrwore: John Hopkine prese, (942). 2. 276 . 
Increase and by the end of March "the newly installed W1son adminlstration found an inextricable mudde on its hands, which Bryan, as Secretary of state, prooeeded to complicate by the worst poseible appointments."101

Informed Dominlcans hoped for a change in pollcy under the wilson adinistration, as both Wilson and his secretary of state Bryan were avowed "ant1-imperlalista." It seemed reasonable to expect such a change, as wilson had announced thet the pollcy of the United States toward Latin America would be one based on equality and that washington wished to bxing into existence a spirit of mutual ldentification and solidarity on the basis of mutual appreciation.

As he himself expressed it:

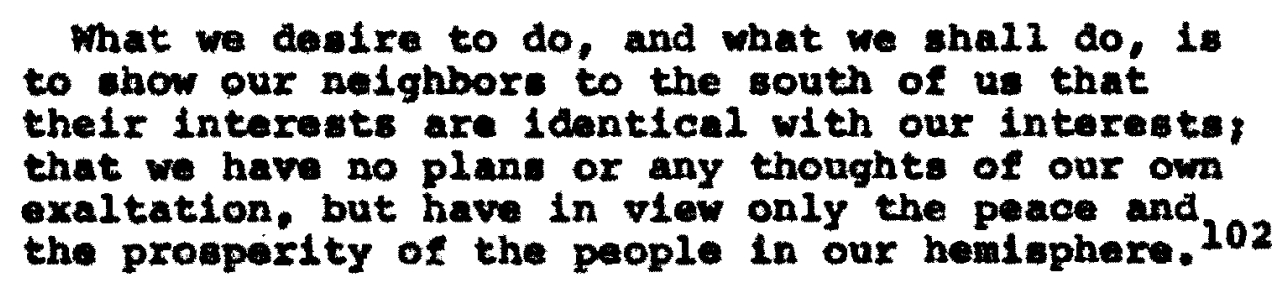

Indeed, when W1son's administration assumed power -1t would," In the words of Dana G. Munro, "have been hard to foresee that his adminietration would go farther than any of its predeceseors in Intervening in the Internal affalra of several West Indian republice."103

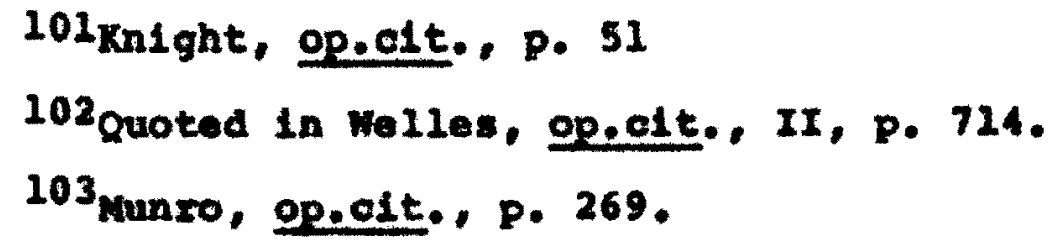


In theory, W1Ison's pronouncements were exceptional

in view of past policles, and created a favourable impresston throughout Iatin America. In fact, however, what was later produced was a series of well-intentioned blunders that led ultimately to military occupation. A large share of the blame for early failure in the Dominican Republic must be placed on secretary of state Willian Jennings Bryan's shoulders, as:

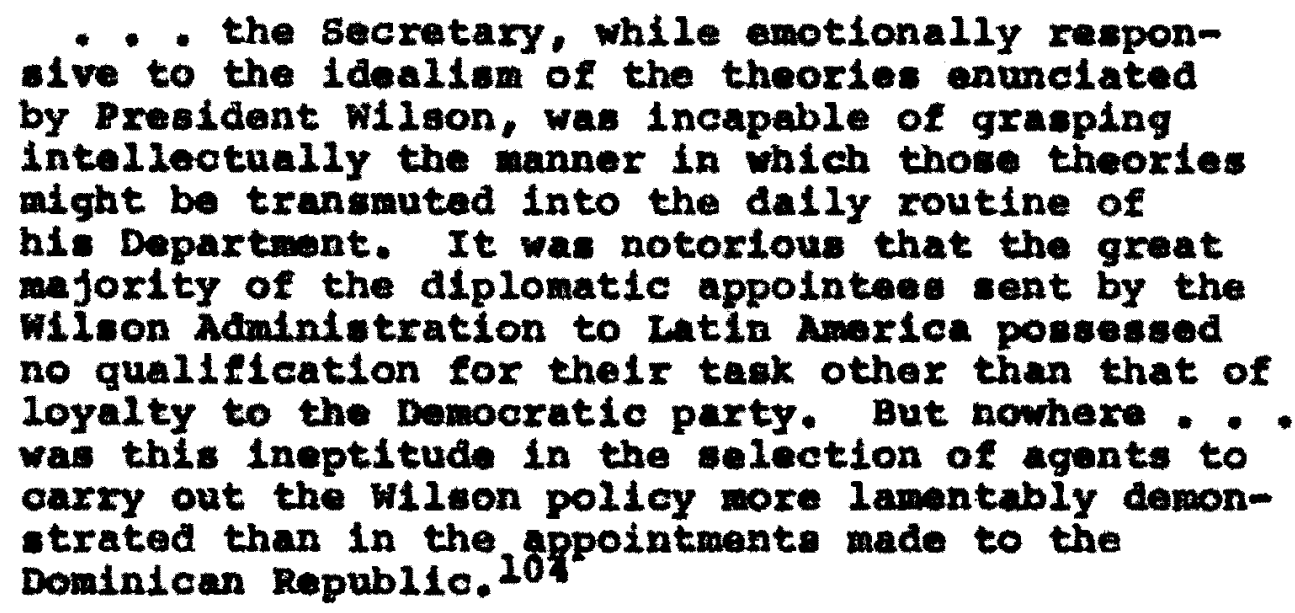

In defense of President wilson it wust be admitted, an

Chester L. Jones notes, that "the problens which here, as elsewhere, confronted the Wilson administration involved peculiar difficultion which it is not by any neans sure that a better-chosen set of officlal. could have overoome, "105 When W11son took offlce he found the Dominican Rapub110 In turmoil. On Apzil 14, the Doninican Congress, after two tortuous weeks of deliberation, elected General José

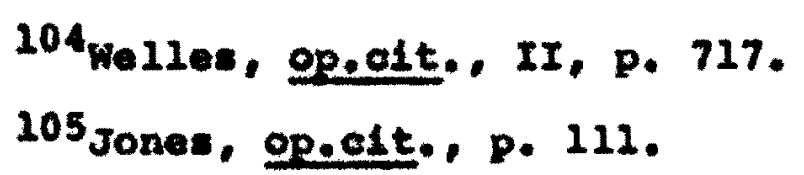


Bordas Valdéz as provisional president for one year. The new president, falilng to Insplre confldence among all political factions, was greeted by rebellion only one day after his inanguration. The situation continued to decay, and by september the revolt had reached major proportion. In the meantime, President wilson, on secretary of state Bryan' recomandation, appointed as Minleter to the striferidden Republic, one Jawes Mark sullivan, whose only qual1fication was that he had been a loyal supportex of the Domooratic Party. 106

After his appointwent sullivan was ordered to proceed Immediately to santo bosingo and was instructed by secretary Bryan to Inform the revolutionary leaders thet the Influence of the United states government:

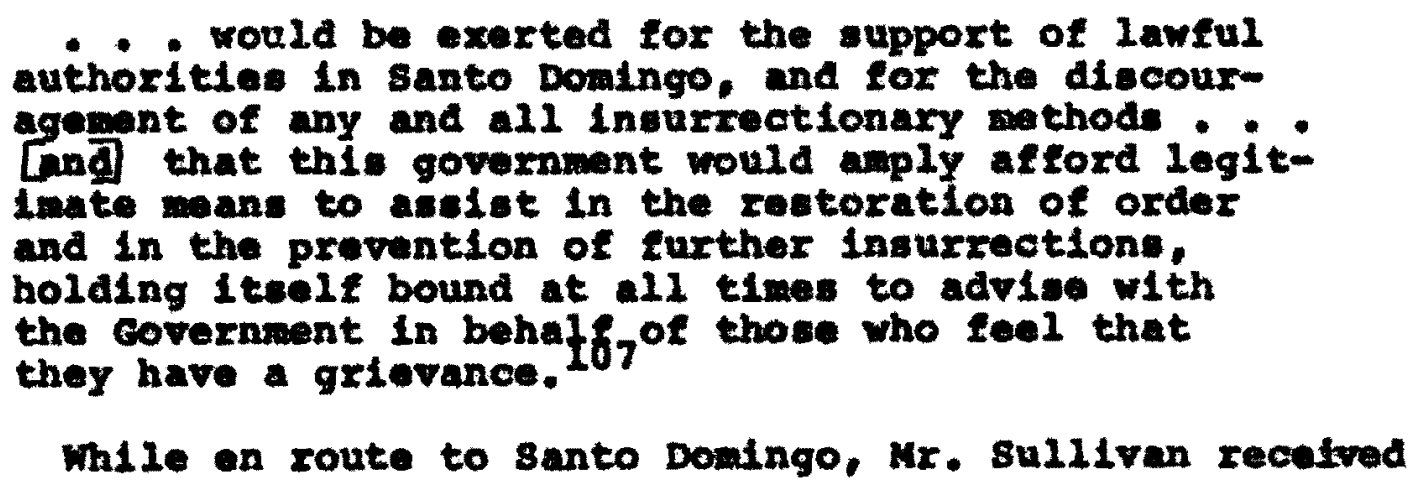
another communtcation from secretary Bryan in whlch he was Instructed to convey the following message to the rebel leaders in puerto Plate. The masage warned the revolu-

${ }^{106}$ Knight, op.c1t., pp. 35-54.

${ }^{107}$ porelon Relatione, op.olt.. 1913, PP. 425-26. 
tionaries that, under the terme of the 1907 agreement, the

United stater would:

\begin{abstract}
- not consent that the Dominican Government increase 1te debte for the purpose of paying the revolutionary expenses and elaime. . . And should the revolution eucoed, this covernment would whid thold reognttion of the de facto governmont, and consequently withhold the portion of the oustom collections belonging to santo Doningo

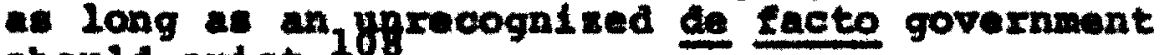
uhould exlet. 10
\end{abstract}

When the above threat, contalning certain features

that ald not seem to be covered by the treaty of 1907, falled to and hostilities between the Bordas govarnment and the Insurzectionists, secretary Bryan, acting on the recomandutIona of Minister sullivan, sent three state Department officlals and thirty assistante to supervise the Congressional electlons in December to Ingure a falr election. This action, certeinly not provided for by the 1907 treaty:

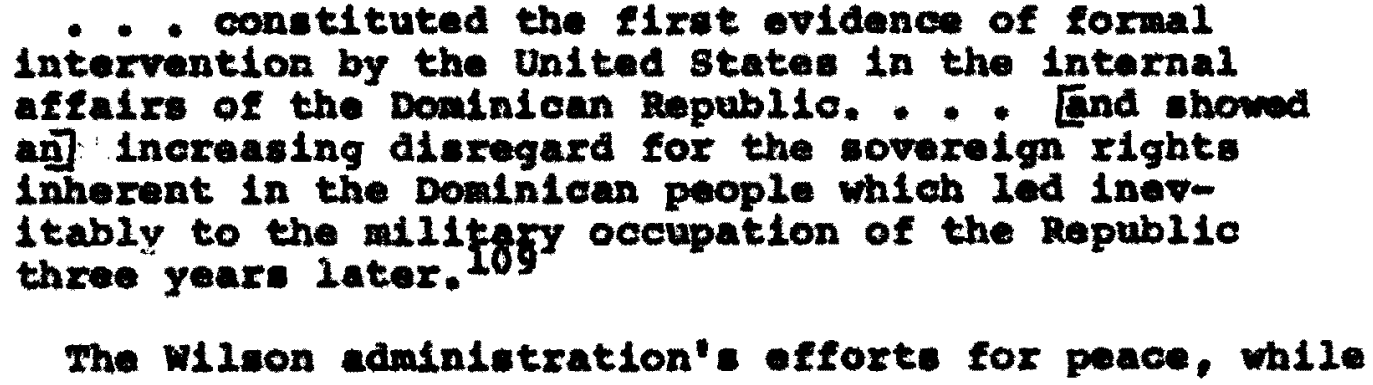
of Presldent Bordas had to adrit thet the December elections were orderly and fair. Yet the opposition wae not eatiafled, ${ }^{108}$ rorelgn Ralatlons, op.elt.. 1913, p. 427.

109 welles, op.c1t.. II, p. 726. 
and political and economic conditions within the leland steadiy woreened during the opening months of 1914. At the beglnning of 1914 the Bordas governmant, through wismanagement of funds and because of large expenditures used to cuxtall revolutionary activity, owed $\$ 386,000$ for back saleries and over $\$ 740,000$ in claims. Congressional members threatened to cauge chaos if their December salaries were not paid and it became clear to the state Department, after advanoling the Bordas Adninletration $\$ 40,000$, that it must once more give consideration to the Doniniean government's need for a siseabde loan.

secretary Bryan, showing a dealre to exercise a degree of control over the Internal affairs of the Bepublio, Instructed Minister sulliran to suggest to Bordas that $\$ 1,200,000$ of the 1907 bonds, up to this time destined for expenditure in the area of public worke, could be sold to pay back salarles and pressing clatme, on the condition that aloohol and tobaco taxes be increased to relmburse the public rorks fund, and on the further etipulation that an Amerioan financial expert be sent to santo Domingo to amsist in anters of accountIng and budgetary control wh a view of helping officials to prevent a deficlt. Bordas accepted this proposal when It was agreed that the sum would be Increased to $\$ 1,600,000$, but Bordas' enenles in Congress blocked the measure ant11 Apr11. In order to cauge hiv Inanclal embarrasenent. It was finally arranged that the "financlal expert" would be attand 
to the customs receivership and that he would possess som degree of power in connection with the government's finan-

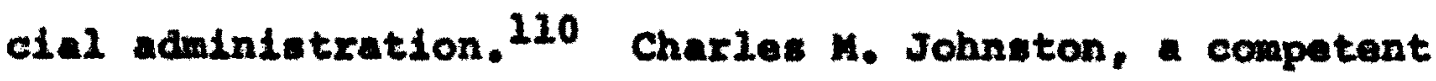
man with experience in Mexico and the West Indles, was selected by president Wilson to fill the position. By now Wilson was watching the deteriorating polltical situation with growing concern. In anguat he assumed more direct control by applying to the Dominican Republic the "Wilson Plan." Milson's plan reaffirmed the altrulatic purposes of the Onfted states but declared that if constructive benefitg were to accrue to the bominican nation, the firet oxder of business was to halt all armed hostilities. This done, he then suggested that the political leaders choose a provisional president who would then arrange for electiona for both the Presidency and Congreas. The alections would be supervised by American observers to insure faimess and Wushington would then reoognize the elected government as one representing the people's wlohes. Once the governiont assumed office, no further revolutions would be permitted by the United states. All changes were henceforth to be made via the Constitutional route.111 wileon's plan seemed to follow and even exceed the earlier dictates of secretary Bryan, for the special comalssionera appointed by President

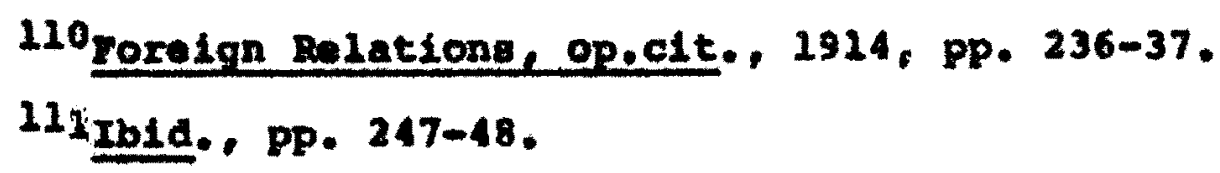


W11son to execute hle plan in santo Doulngo were Instructed thusly: "Wo opportunity for argument would be given to any preson or zaction. It is desired that you present the plan and see that it is complied with."112 According to the astute sumer welles:

President W1ison Inplied that the government of the United states possessed the right to assure itself of the continuance of orderly constitutlonal government in the Dominican Repubilc, and would "Eel at 11 berty" to prevent ali changes in the Covernment of the Doulnican Republlo other than those by the "peacerul 1 processes" provided In the Doulnioan Constitution. 113

W11mon's combinstoners, the former Governor of Hew Jereey, Frankiln Fort, and Charles smith, a New Hampahlre attorney, secured accoptance of the W11son Plan from all the prinelpal leaders except Desiderio Axias. Thereupon, President Bordas resigned and a phyalclen, Dr. Rawón Báez, a son of Buenaventura Báex, who had never actively engaged in politics, was elected Provisional president on Auguat 27. 1914. Following his Inauguration, President Báex, after consulting with the Onited states Cominsioners, axranged for national electlone for a President and a Congress to be held in six weeks. It was also agreed that the electlons would be obeerved by Americen representatives to Insure falrnese.

The principal candidates were of the two historic

$$
\begin{aligned}
& 112 \text { mb1d., p. } 247 . \\
& 113_{\text {Nelles, op.oit., II, p. } 738 .}
\end{aligned}
$$


partles, with Juan Inldro Jimónez representing the Jimenistas, and Boracio Víaguez the Boraclates. The elections took place on October 25 and resulted in a narrow victory for Jimónex. It wut be noted, however, that the Jimíner forcea made two important political deals which insured victory: one was with a third party candidate, Federico Veláequez, who was persuaded to throw his total support to Jiménez in return for control of 25 per cent of the fobs in the new government, and the other was with Dealderlo Arias who, for his eupport, was pronlsed a Cablnet position. secretary Bryan, convinced the electlons had represented the w111 of the people, declared on November 14, 1914 thats

The perlod of revolutions is past, law and order w112 be upported; necessary reform $w 111$ be urged through legielation. It $1 \mathrm{~s}$ belleved that under anch a pollcy 1 pgace will be followed by prosperity and progress.

For a fleeting momont, it seewed as if the tiny nation would enter upon an era of peace and prosperity, but the Indistance of the state Department that Jimines place the collection of Internal revenues under the recelvership and g1ve Charles M. Johnston, the "Iinanclal expert," officlal recognition as controllex, soon brought revolt once more to the Latin Bepublic. The state Department felt that domertic reforms were needed if democracy were to flourleh and that the area which needed the most attention was the admin124 Eorelon Relatione, op.c1t.. 1914, p. 256. 
iatration of government Ilnances. such a proposal was not calculated to caube much furor as, during and after the electorial canpalgn, Mashington had recelved ansurances in writing from Jimber and the other candidates that they were in favor of placing the internal revenues under the customs recelvershlp. 115

That refors was needed cannot be denied. Barlier loans to Archblehop Nowel had been squandered in suppressing revolte, and short-term loans approved for various projecte had been misued and Interent payments were long overdue. To add to th1s financlal misory, thare vere practioully no tax receipts avallable to the government as the Bordas adninistration had persuaded morohants and industriallete to pay thair taxes in advance in return for a reduced rate. President Jimónes was also confronted with an Mrias dominated cablnot and "attempte at reform had no further result then to atinulate violent opposition."116 sady, President Jiménes; now aged and infirm, contributed to the deterioration of the situation through his lack of energy in adopting strong weasures.

It was in February 1915, only a week after the Pres1dent'. Inauguration, that secretary Bryan, seoking to enlarge in scope his ultimate policy of vesting the ultimate decinich

$$
\begin{aligned}
& 115_{\text {munro, op.oft., p. } 296 .} \\
& 116_{\text {Bchoenrtoh, op.elt., p. } 90 .}
\end{aligned}
$$


regarding the domestio policies of the Donintcan covernment In the hands of representatives of the united states, informed president J1ménez that he was expected to extend forwal recognition to Mr. Charles M. Johnston, W11son's appointee as "Inancial expert," as Comptrollex of the Iinances of the Dominlcan Republie, and that his duties would be to:
- provide a budget for the Dominioan Republic based upon his knowledge of income and probable expenditures. this budget to be rigidiy adhered to to approve and countersign any payments made by the Dominlcan covernment, it belng understood that no payments be valid uniese conntersigned by the comp-

In addition, Internal revenue was to be placed under the recelvershlp and public works were to be put under an Amer1ean, accountable only to the United states state Department. It was also suggested that united states assistance be obtalned for organising a constabulary offlcered by United States pareonnel that would replece the Dominloan Army. The latter step was seen as one that would irrevocably put an end to political aleturbance.

When Jiménes attampted to abtain the approval of the Doninican Congrese to secretary Bryan' proposed masures, he was greeted by etiff opposition from the Hoxacista senatore and frow the cronles of Arlas. Arias argued againet followIng United staten dictates, but it was genorally recognized

$$
{ }^{117} \text { Fore1gn Relat1ong, op.c1t., 1915, p. } 297 .
$$


that his opposition:

was unable to increase the subsidy which he had
already commensed to pay him and was unwiling to
carry out all of Arias' deptfes with regard to
governmental appointments.

Jiménez feebly presmed for acceptance of Washington's proposal that Johnston be given official recognition as controllex, but when the Dominican Congress twice refused his request, he took the position that Johnston could have no legal authority. The State Department was determined to stand firm, however, and insisted that Johnston continue to countersign all checks covering governmental expenditures. As a result, "the status quo continued for some months, with constant friction between the controller and the president and with 11ttle beneficial effect on the Republic's financial atuation."119

State Department officials were also disappointed in their hope that a Exeely elected government would lead to a quieting of internal unrest, for simultaneous with Congressional unrest was the threat of an armed Insurrection by Quirico reliú, the Governor of Puerto plata. Acting on reports that linked the coundrel Arias with Feliú, secretary of state Bryan instructed the American Miniater sullivan to assure Jiménez of continued support and to inform

$$
\begin{aligned}
& 118_{\text {wallee, op.e1t.. II, pp. 749-50. }} \\
& 119_{\text {Munro, op.e1t., p. } 297 .}
\end{aligned}
$$


the dissident leaders that they would be held personally responsible for any attempt they might make to embarrass the government. In his cable to sullivan, the secretary of State further stated that:

Th1s Government means what it sald when it sent a conulssion there with a proposal looking to permanent peace and it will live up to the promises it has made. . . The changes advised $[\bar{f} . \theta$. the reforms demanded are the reforms necessary for the honest and efficient administration of the Government and the early and proper development of the country. There should be no unnecessary delay, therefore, in putting them into operation. $10^{\circ} A$ naval force will be gent whenever necessary. $120^{\circ}$

oltimately, the threatened revolt in Puerto plata was headed off, but it need be noted that negotiations only became successful when the U.S.S. Castine anchored in the harbor off Puerto Plata with large body of American Marines aboard.

A problem of a different nature arose in April when Sullivan reported that the Dominican Congress had initlated impeachment proceedings against president Jiménez for his fallure to dismiss Johnston as controller. Congressional hostillty toward Johnston was activated by his decision to suspend payment on a number of superfluous budgetary items submitted in March by the Dominican Senate and by the attempt of Clarence H. Baxter, the General Recelver, to set up a civil service system within the recelvership. The need for the Dominican Government to live within its income was

$$
{ }^{120} \text { Forelgn Reletions, op.c1t., 1915, pp. 279-80. }
$$


apparent to informed observers, as was the need for a more orderly arrangement within the recelvership/ but congresa had twice refused Johnston's appointment and stood on EIrm Conatitutional ground in its attack agalnst Jiménez for his falluxe to follow Congressional dictates. Secretary of state Bxyan, upon recelving woxd of the proceedinge and the report that certain mombers of the Domintican Congress hoped to install Arias as Provisionul President, imodiately instructed sullivan to inform those involved that Wanhington would not:

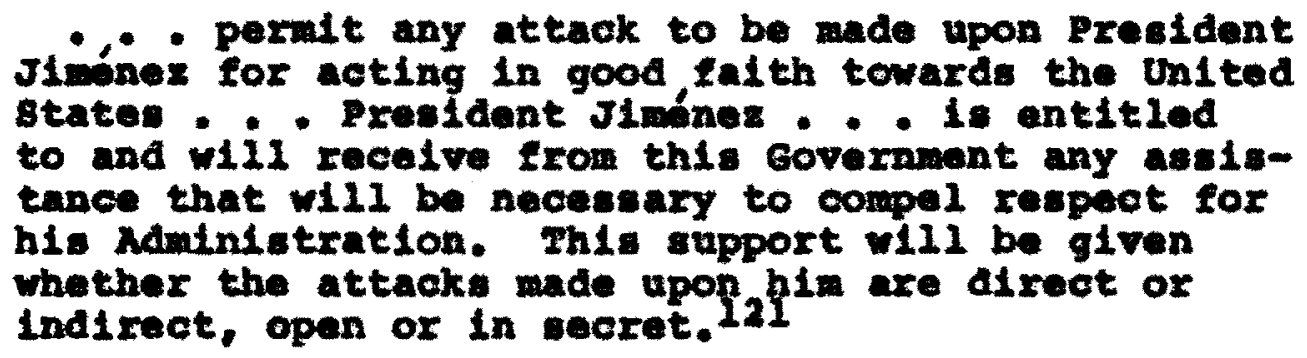

The secretary of state's mossage had immediate effect on the Dominican Congreas and impeachment proceedinga against Jimónez were, for the tlme beling, abandoned, but a dangerous course of pollcy had been set into motion, for secretary Bryan had completely ignored the right of impeachment given the Dominican Congress by the Dominican Constitution and "had passed the atage when he considered that the dcaset1e affairs of the Dominloan Republic were other than a matter $20 x$ the sole determination of the Dopartwent of stata 222

$$
\begin{aligned}
& \text { 121 Forelon Relation, op.c1t., 1915, pp. 283-84. } \\
& \text { 122welles, op.c4t., II, p. } 752 \text {. }
\end{aligned}
$$


The controverey which involved United states control over the appointwent of all customs officials was settled more amicably by a Dominican compleston whloh met with President wilson and secretary Bryan in the latter part of Apr11. They were varaly greeted, and although the state Departaent tood firm In Ineiating on adherence to the origInal 1907 agroement which gave them ultimate power over the appointment of custom personnel, they:

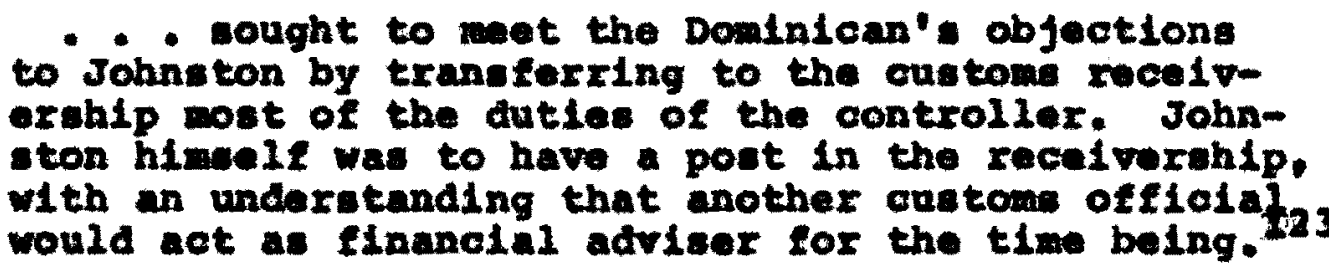
Not expecting euccesa, the Dominican Cominsioners were pleased with the now arrangesent and salled for santo Dondrgo to celebrate one of their few diplomatic victorles. As the summer of 1915 approached there were significant changea made in state Department personnel. In May, sullivan was compelled to resign and in June, Secretary of state Bryan turned over the reing of leaderahip to Robert Lensing. As early as December, 1914, President w11son had been Informed of certain Improprieties on the part of sulIIvan and had appolnted Senator James D. Phelan of Callfornia to lavestigate the allegations. The press immediately began to explore the charges againet Sullivan and

$$
123_{\text {Munxo, op.01t. p. } 301 .}
$$


so damaged his Image that any credibility he might have had was soon lost. The coup de grace was delivered when Senator Phelan released his findings on May 8, 1915. Summaxizing his report, the Senator took into account an alleged brlbe whlch was offered to a state Department off1cial who had Investigated Sullivan's improprietiess

I an not satisfled beyond a reasonable doubt that Mr. Sullivan fully realized the grossness of the impropriety of his proposition, but I am satisfled because of his proposition that he is not a properf person to hold the position that he does

sullivan had remalned at his post for over four months before his resignation, and one aust agree with Dana $G$. Munro's statement that it was indeed "extraordinary that the American government should have attempted for several months to deal with so potentially dangerous a situation through - representative who was completely discredited. 125

During the sumber of 1915 the political atmosphere in the Dominican Republic once again became charged. Local rebellions by disaffected provinctal leaders flared anew und by July an Insurrection headed by General zenb́n ovando in the Province of san Pedro de Macoris threatened to engulf the tIny Republic in rovolution. At this juncture, President Jimónez suffered a phyaical and mentel breakdown and was obliged to turn the reins of governmental control over to his 124 quoted in knight, op.c1t., p. 65.
$125_{\text {Munro, gp.cit., p. } 301}$ 
sharply divided cablnet. Sensing the serlousness of the situation, Secretary Lansing Instructed the Americen Charge d' Affaires on July 21 to inform those principally involved in the disturbances that if it became neceseary to land American soldiers to estabilsh order he would not hesitate to do so. General Horacio vásquaz, as leader of the oppon1tion, quickly asserted his party's desire for peace, but in an open message to Lansing he declared that,

I believe that the peace of the country can be flrmly astablished not by troops but through good and respected institutions. . Moreover, I do not believe that President wilion has the right, under any pretext, to infringe the sovereignty of an independent people. . I consider as Indispensable both respect for public 11berties and for the law on the part of the Government in 9 foder to attain the onds which we so much desire. 126

The altuntion remained touchy unt1l the Fall monthe when Jiménex once again resumed his post and guieted the revolutlonary leaders by distributing among thom numerous road bullaing contracts and appointments to positions within the government. Politicaliy, the situation was, for the mom ment, in hand but wach a "weak and temporizing polley" could only lead to future difficulties. 127

The changes in state Department pereonnel had, for a

fleeting moment, given rise to speculation among Dominlcans

${ }^{126}$ Quoted in Welles, op.c1t., II, p. 756.

127 Forelgn Relations, op.cit., 1915, pp. 292-95. 
that American foreign policy might be softened to allow the Dominican government more leeway in her congreseional activities and that the Convention of 1907 might be reinterpreted so as to give Dominicans more control over expenaltures. Dominlcans soon found out, however, that although a change had occurred in American representation, there was to be no change in American policy, indeed, Secretary of State Laning sought "to reaffirm the pollcy gradually noulded by secretary Bxyan with the at least tacit approval of President wileon, . . [and undertook] to obtain for the Ondted states an even graster weasure of control. .128 Because of the continuing disordex within the Republic and the foeling among many State Department officials that financial direction of Dominican affalxs wat neceseary to prevent recurring revolutions, secretary Lansing in september instructed William $W$. Russell, the now American Minister, to Inform the Dominican Government that it was increasing 1te public debt in violation of the 1907 Convention. Fussell was also told to convey the fact to the Dominlcan Government that $\$ 7,000,000$ dollars of public indebtedness had been contracted without United states approval and that $1 f$ the original objects for which the convention had been secured were to be upheld future violations of the Treaty could not be allowed. In oonnection with secretary Lansing's statement 128 welles, op.c1t. II, p. 758. 
It must be remembered that in July the neighboring republic of Haitl had been plaoed under United staten military ocoupation. The ocoupation of Halti would have far reachlng consequences for Dowinlcans for:

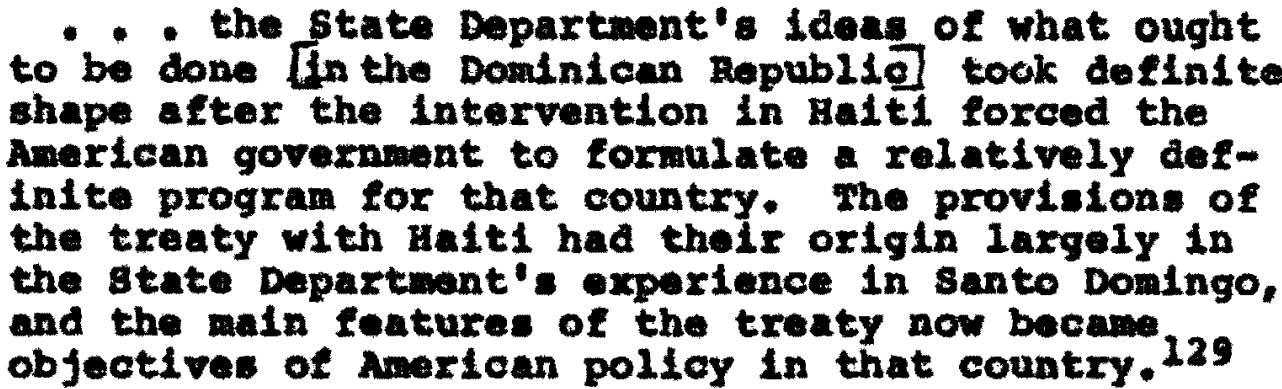

What Lansing hoped for was the adoption of a new convention which would be elmilar to the one recently coneluded with Halt, with provisions for a land survey to facilitate taxation, for constabulary hoaded by Americans, for a core of Amerloan engineers to overeee pablic works and aen1tation, and for the approval of a financial adviser who would have the ultimate decision in budgetary antters. If a now treaty could not be secured, Iansing instructed Russel1 to advise the Dominican government that under the terms of the 1907 Convention the United states had the legal right to: (1) compel the observation of article III of the convention in the appointment of Einancial adviser and, (2) to provide for the free course of customs by the creation of a constabulary. 130

129 munro, op.c1t., p. 302.

130 rorelon neletions, op.c1t., 1915, Pp. 321-25. 
Dominlcan governmontal leaders almost unanimously rejected the thought of ratifying so odious an agreement as had been accepted by Hait 1 and protested vehemently agalnat Washington's Interpretation of the 1907 Convention. Iansing, for the time being, did not press for acceptance of a new treaty but did Ineist on Dominican acceptance of

a Inancial adviser and the creation of a Constabulary. Under such cirowntances Jimbnez" position as President was particularly precarloue. On the one side, Arlas was constantly intriguing against the alling executive in the hope of replacing him as provialonal president, and although Jiménex did possess a coterle of loyal and able officlale he needed Inanciel assistance in the form of loans to maintain his aduinistration. This the state Department was unwillths to allow unless theit demende regaxding the convention of 1907 ware met.

Events came to a head on Apr11 14, 1916. W1th the ald of the Velfigues faction in his Cabinet, Jimínex corawitted himeelf to a course of action designed to lessen the Influence of Arlas, who at the time was Minister of war. Ceneral Cesareo Jiménez, Chlef of the National Guard, and Ceneral Hauricio Jimbnez, Comander of the forces statloned in the capltal, were sumoned to a sall estate a few wiles from the copltal where they vere arreated for dieloyalty to the government and fox venality in thair 
offletal dutles. Arias was also summoned for an interview with Jimánex, but was alerted to the fact that his chlef lientenants wera under arrest. Belleving Incarceration avalted hlm, he headed for the fortress in Santo Domingo where he shut himele up with troops loyal to his person. Within a short time the remalnder of the army along with the major opposition parties declared for Arias. Hoping to head off a general rabellion, the American Minlater Sullivan jolned with Archblehop Nouel in an effort to reach some wat of compromiee with Arlas. Unfortunately for all parties concerned, no agreement was reached. By hay 1, it was recognized that the break botween Arias and Jiménez was a permanent one. Congressional allles of Arlas Impeached Jimenes, and he in turn dismissed Arlas from his Cablnet position.

In a raxe dieplay of decisiveness, Jindnex collected about his 1500 troops which were supplied by Provinclal governors still loyal to him and marched to the outskirts of santo Domingo where he sent onvoys to Arias demanding his 1mediate surrender. Fearing a possible celsure of the Presidency by the Cormanophile Arlas, secretary Iansing urged Jimánez to request the assistance of United states Marines who had conveniently stationed themselves in santo Domingo harbor aboard the U.S.8. Pralrie and the U.s.s. Castine. The Dominican executive at flrat seemed willing to sumon American Marines, but aftar considerable debate he concluded that the Dominlean people would oppose forelgn 
troops on their sol1 and modifled his position by asking only for arme and amunition for his troops. In a decision which must be questioned, Lansing informed the American Minister that Jiménez must resticict himself to asking only for the eupport of Anarican troops.

In the mantime, American Marines were landed ostensibly to protect the Marican Legation and the Haitian Legation, which was serving as a refuge for forelgners. Jimónes declded to press the attack, but a shortage of mi11tary eupplies prevented his taking the capital. Now totally despondent; be acked the American torces to take the city for him, but within a matter of hours he withorew this request and resigned, 131 By resigning, he hoped to escape responsib111ty for the ever growing number of Marlnes being landed without his permission. In an address to the nation he. announced that:

- I colemnly declare that I hold the norxowful conviotion that an armed encounter between my torces, those who are upholding the constitution, and those which occupy the rebel stronghold of the Capital of 8 anto Domingo would inevitably bring as a result the ihumlilation of a North Nierican intervention. . - Ince the authorg of the coup d' etat. - vere dieposed to destroy the Nation rather than renounce their lust for power, the president was forced to alect one of two alternatives: elther to return to the Presidential Manslon among ruina to enjoy a power regained for him

131 Munro, op.c1t.. p. 306. 
by forelgn bullets, or his own inmolation. . . with the whole country at my side. . I Fithdraw to the serenity of a tranquil home. 132

Instead of preventing further American military intervention, Jimónex" reaignation resulted in an increase in the number of troope stationed outelde the capital. Congreostonal leaders loyal to Arlas were alarmed at the presence of American forces so near the capital and cent the following message to President wilson:

The transport prairte has arrived with troops, but the Doninican people have confldence that these troops w111 not be used by any means to Interfere with the free action of our institutions. The Iegislative power of this country is responsive to the needs of the wole country and clalng fult responsibility for its institutions and 1 ans. 133

Other frotest followed but were of no avall, as the number of Maxines was increased et111 further with the arrival of Rear Adniral W.B. Caperton aboard the U.8.6. Dolphin. once Jiwénex' realgnation appeared final secretary Ianelng extended full control to Minister Ruseell as to what actions should be taken and as to how smarloan troops were to be used. Constitutionally, executive power remulined in the hands of the cabinet until a now President was chosen, therefore, Rubsazl decided to recognize Its authority. In conjunction with his recognition of the Dominican Cabinet

132 J1mónez' proclamation of May 7, 1916 is quoted In Welles, gp.clt.. II, PP. 769-70.

${ }^{133}$ guoted in welles, op.e1t., II, p..771. 
Russell also resolved to clear the capltal of the rebels under the command of Arias. He instructed Caperton to take the necessary action and on May 13th the Admiral advised Arlas that the United states would support the constituted authority of the Republic and that if the revolutionaries had not surxendered santo Domingo by $s 1 \times 0^{\prime}$ clock on the morning of the 15th, American forces would move to disarm the ingurgents. Fortunately, Arias avolded bloodshed and on the night of May 14 th moved his troopg to the interior. The next rorning Caperton's forces entered Santo Domingo and a military occupation was proclaimed. Proclaiming the cap1tal occupled, Caperton addressed the following message to 1ts citizens:

I. Owing to the conditions that have existed in and around this City in consequence of the fact that rebels in arms have taken possession of the city, excluding therefrom the constitutional offlcials of the cuvernment, and after all means to arxive at a peaceful settlement of the situation had been exhausted, it became necessary to have the city occupied by forces of the United States of Anerica.

II. Notice is hereby given to the oltizens of Santo Domingo that the forces of the United states of America have assumed control of this City.

III. All the inhabitants are requested to stay in the City and cooperate with me and my representatives in protecting 11 fe and property and maintaining order.

IV. All public officials are asked to remain at their posts and cooperate with me. 134

${ }^{134}$ Eoreign Relations, or.cit., 1916, p. 228. 
Dominicane were naturally resentful of the Amerlcan presence In Santo Domingo and became sorewhat hostile when Caperton ordered the principal olties of the interior occupled as well. 135 Little did Dominicans know that this was only the first step in an occupation that would last a full elght yoars.

In the eyes of many Dominicans, Arlas had been discredited by his cowardly exit from Santo Domingo, but this did not keep the Congress frow attempting to secure his election as President. With the troublesome interior almost occupled, the American Minister Rusall decided the time was propitlous to press for the reforms that the state Department had for so long advocated. To implement the long sought after reforms, however, Russell had first to block the election of Arlas. He "suggested" to the Dominican Congress that they delay their cholce of a Provisional President unt1l more normal conditions prevalled within the Republic. The Dominican legislators, however, refused to adfourn, but being realists in an occupled country, thoy declded the election of Arlas would be wholly unpractical and imediately started the search for a compromise candidate.

On May 23xd, both the House of Deputies and the senate had agreed on the selection of Dr. Federico Henrlquez $y$

${ }^{235}$ porelgn Relations, op.c1t., 1916, p. 227. 
Carvajal as Provislonel President. Rusell and Caperton, homaver. moved to prevent IInal action on his nomination. They did so because of his friendship with Arias and because he refused to enter into any pre-election agreemente which would guarantes Washington the latitude in pollcy which so many top ranking state Department officials were demanding. musec11 suggested to Hashington that sowe of the more m111tant senatore be placed under arrest in order to block the election of Henrlques. Weshington vetoed rueselle suggestion and inetructed him to inform the Congress that any uneatiefactory government would not be accorded recognition, and that no customs revenues would be released for 1to malntenanoe. Independently of Rused $11^{\prime}$ action, the Cound 1 of Ministers, under the leaderablp of Velágque. Incarcerated ceven of Ar1un' supporters in an attempt to stave off the election of an Eoracleta as President. Runee11 Imediately obtained thelr release, but Henrfquex thought the plot had been Instigated by the United states to threaten the Domintcan Congrese. Henrlguez was, however, shrewd enough to comprehend the sate which awalted hin as President, and in a moseage to the people he declined the Presidential nomination and hurled abues at the United states for interfering in Doainican politios. With HenxLques out of the running, the Dominican Senate moved quickly to secure the election of Jacinto de castro, an old lollower of ceneral Víques. The House of 
Deputies, however, blocked his election because of his affillation with the Horaciata party, and once more a deadlock was produced. In the meantime, the occupation of the Cibao became complete with the surrender of Arias at Santlago on July 6th. In a message to the Dominican people Caperton declared that:

It is not the intention of the United states Government to acquire by conquest any territory In the Dominican Republic nor to attack ite sovereignty, but our troops will remain here until all revolutionary movemants have been atamped out and until such reforms as axe deemed necessary to Insure the future velfare of the country hayg been Initlated and are in effective operation. 136

By July'g end the Dominican Congress agreed on the election of ex-President Archbishop Noue11. Noue11, however, even though assured of Russell's support, declined the nomInation. By conatitutional 1imitation Congress was due to adjourn on July 26th. Rather than leave the selection of a Proviaional Prealdent to a Councll of Minlaters friendly to the United states, the legislators, without consulting Russell, elected Dr. Francisco Henríquez y Carvajal, the brother of Dr. Federico Henrlquez y Carvajal, as Provisional president for a period of five months. Henrlquez had, for the past twelve years, 1solated himself from Dominican pol1tics by taking up residence in Cuba. Although his sympathies lay with the Jimenista party, Dominican leaders felt

$$
{ }^{136} \text { roreign Ralations, o-.o1t., 1916, pp. 231-32. }
$$


he would be acceptable to Washington. Hope soon turned to dismay, however, as Russell, unable to obtain any preelection promises, was instructed to withold official recognition until the new President-elect consented to all of Washington's demands for reform.

Upon arriving in santo Domingo, Henrlquez was informed by Russell that the United states would not recognize his government unless he acquiesced in the interpretation of the Convention of 1907 as outlined in earlier notes to President Jiménez. Without any further attempt to resolve differences at the conference table, Russell recelved instructions to suspend all payment of Dominican revenues. Washington's actions in this matter, whlle reprehensible, were designed to demonetrate to Henrlquez that the United states could and would assume and malntain a rigld posture until Its demands were met. The imediate effect, however, was that Henrlquea became intransigent and government employees and local merchants found it diffeult to maintain themselves without funds. 137

Henrlquea romained firm, arguing that the Dominican Constitution did not give him power to affirm agreements without the consent of the Dominican Congress. He was, however, willing to temporarlly acquiesce in the collection and disbursement of receivership funds and consented to the

137 Munro, op.ctt., p. 309. 
reorganization of the Dominican Army if the United states would allow other Latin American nations to provide officer to ass ist in the overhaul. Washington, however, realized these agreements would be of a trangitory nature and that a new treaty would have to be negotiated once Henrfquea. government was accorded recognition. What the state Department wanted was an "Iron-clad" agreement that would permit the creation of a constabulary and would assure Onited stater flacal control. Slnce Henrfques' proposals fell short of this mark, they were rlatly refused.

After prolonged consultations with his advisers, Henrlquez once more attempted to reach a compromise in late August. A treaty was proposed which would have given the United states complete control over the Republle'. finances and would have employed American Army officers under fouryear contracts to reorganize the Dominican army. The only point Henrlquez atood flrm on was that Dominican offioers would continue to receive their appointments by the Dominican President. Admiral Pond, who had replaced Caperton in July, seems to have been impressed by these overtures, 138 but the state Department remained intransigent and curtly refumed further negotiations.

Early in October, Russell was called to washington for a conference with secretary laneing to comanicate his

$$
{ }^{138} \text { Ibid., p. } 310 .
$$


recommendations on future policies. The American Minister was for the presenting of a final ultimatum which, if refected, would mean that the United States would have to "take charge" of the nation's affairs.139 Lansing apparently agreed with Russell, for an urgent plea from Henrlquez that some solution be adopted which would not obliterate Dominican sovereignty went unnoticed. 140

By November the State Department had lost all interest in any further attempts at negotiation. Washington had concluded that a formal military occupation was the only remedy for the 1118 which plagued the beleagured Republic. To a large degree it was influenced by the American occupation of halti where full military control had resulted in the adoption of a treaty that contained all the provisions for reform that Washington wanted. There were, however, other equally important considerations aside from the Haitian experience, which help explain Washington's decision to go ahead with a military occupation. One of the principal reasons for state Department intrangigence centered around the fact that the ultimate value of any agreement would depend on the attitude of the Dominican Congress and the President who would succeed Henrlquez when his five month term expired. Prospects for

${ }^{139}$ Russell to Lansing, September 25,1916 quoted in Munro, op.cit.., p. $3 n$

140 welles, op.cit.. II, p. 790. 
cooperation were anything but bright. When Henriquez was elected, Dominican politicians had reconvened the constitutional Convention olected in 1914, with a view toward reforming the constitution. From the start there was discord within the convention. To Insure a quorum it was necessary for sixteen members to meet, but day after day the Ilmenistas refused to attend. The only business accomplished was the adfournment procedure. In the absence of const1tutional changes, the electoral colleges in several provinces met of their own volition and returned the electors of 1914, a majority of whom were Jimenistas. While this action was clearly 11legal, what bothered the state Department was the fact that most of the members contemplated the election of Arias as President. The prospect that Arlas might secure the presidency was not contemplated with equanimity in washington. Offlcials regarded him as a political and military bully who had extorted money from the Dominican Government for over a quarter of a century. Aslde from his caudillo activities, he and many members of his party were outspokenly pro-German. 141 In the minds of many, a government headed by such a man presented a security risk in the Caribbean; this Washington would not permit.

For a time, the United states had profited by the general frlendliness exhibited toward Americans. By Hovem${ }^{141}$ Munro, op.c1t.. pp. 311-13. 
ber the mood of the people had changed to one of open hostility. During the month of September, American Marines had gradually assumed many of the roles traditionally assigned to the Dominican police force. Armed patrols began making arrests of Dominican citizens. By October Russell compl1cated the situation further by ordering the arrest of several caudillos who had sacked the customhouse at La Romana the summer before. In an attempt to seize one of these men, Ramón Batista, a fight ensued which took the lives:of two Marine officers. Two days later, on october 26th, an encounter with a drunken gunman in the capital resulted in the deaths of several innocent bystanders. American military personnel also attempted to impose a censorship on the more radical Dominican dailles. Such actions, while well intentioned on the military's part, understandably provoked the utrost resentment on the part of many Dominicans. Hostility toward Amerlcans was also generated by the fact that for four months Washington had suspended all payments to the Dominican government. The suspension of salaries to governmental agencies and employees had brought about an intolerable economic situation which had left many Dominicans destitute.

By the middle of November, Secretary Lansing realized that the situation was fast approaching a crisis. On November 14, Henriquez had requested that the electoral colleges 
choose new senators and deputies to replace those whose terms had expired. The state Department feared the alection of Arias after evaluation of the situation, and decided that Immediate action was necessary. On November 22, 1916 , Secretary Lansing expressed his fear of "economic disaster" and "Impending revolution" within the Republic, citing, - . the fact that the Provisional Government wil not meet the views of the United states in regard to the establishment of financial control and the constabulary, brings the Government of the United States face to face with a serious problem. . The withholding of the funds by the Un1ted states Government on account of the fact that recognition has not been granted to Henriquez has brought an economic crisis in the country which is dally growing worse and for which this Government would not wish to be placed in such a position that it would be held responsible. ... It is thought that the only solution of the difflculty would be the declaration of martial law and placing of Santo Domingo under military occupation, basing this on the interpretation which the United States has given to the Dominican Convention of 1907 and also upon the present unsettled conditions in the Republic. . Captain Knapp - : Is understood to have arrived today in Santo Domingo and it is belleved that no time should be lost in instructing him to put into effect the proclamation declaring milltary control and to commence imadiate $\mathrm{H}_{2}$ the disbursement of funds under martial law. 142

When President wilson replied to Lansing's memorandum on November 26,1916 , his thoughts were elsewhere. As Sumner Welles points out:

The immense upheaval which had resulted from the outbreak of the World War, the constantly increasing

142 Forelgn Relations, op.c1t., 1916, p. 241. 
evidence that the United states might not be pernitted to remain aloof, and the activities of $h i s$ own electoral campaign, had made $1 t$ lncreasingly diffloult during the preceding year for president Wilson to devote much attention to the Dominican situation. The successive steps which had been taken during the aumer months, while duly reported to him, had doubtless not impressed themselves upon him in their full gravity, since his mind had by 13

In approving the military occupation, Wilson did, however, strike from the proclamation the entence which would have authorlzed the officer in charge to remove any Dominican fudge considered unflt. W11son's reply to secretary Lansing read as Eollows:

It 1 w wh the deepest reluotance that I approve and authorize the course here proposed, but I an convinced that $1 t$ is the leavt of the evils in sight in this very perplexing ituation. I therefore authorize you to lssue the necessary instructions in the premises.

I have strlaken out the sentence in the proposed proclamation wich authorized the comanding offlcer to remove judges and others in certain clrcumstances. It may be necessary to resort to such extrem measures, but I do not deen $1 t$ wive to put so arblfrgry an announcement in the proclamation itse $11.174^{-1}$

Henriquez met with Captain H.B. Knapp, who had replaced Admiral Pond in November, in a final interview on November 28,1916 , but nothing was accomplished. The next day a military occupation was proclalmed, which in the words of

$$
\begin{aligned}
& \text { 143we1les, Op.c1t, II, p. } 792 . \\
& 144 \text { Forelgn Relations, op.cit., } 1916, \text { p. } 242 .
\end{aligned}
$$


Sumner Welles:

Dominican Government established, in accordance
with the Dominican Constitution, by the Dominlcan
people, in the exercise of the rights inherent in
them as a sovereign nation, a nation which had main-
tained its liberty and independence against every
menace and against overwhelming odds during the
preceding seventy-two years. 145

The official proclamation based the intervention on the Dominican government's violation of Article III of the 1907 Convention. It was stated that the occupation was undertaken "with no immediate or ulterior obfect of destroyIng the soverelgnty of the Republic" but rather was designed "to give aid to that country in returning to a condition of internal ordex that will enable it to observe the terms of the treaty aforesald, and the obligations resting upon it as one of the family of nations."146 Almost a week later, the Dominican Minister in Washington, Armando Pérez Perdomo, filed an officlal protest. At the time, Perdomo's protest recelved little attention, but as the last official act of an occupled nation, the words today carry a poignant message. He stated that:

A state of war which alone could have justified such a proceeding on the part of the Government of the United states toward the Dominican Republic has never existed between the two Nations. And therefore by acting as it has with the Dominlcan Republic, Your Excellency's Government plainly

$$
\begin{aligned}
& \text { 145 Welles, op.cit., II, p. } 793 . \\
& 146_{\text {Forelgn Relations, op.c1t., 1916, pp. 246-47. }}
\end{aligned}
$$


violated in the first place, the fundamental principles of public international law which laid down as an invariable rule of public order for the nations the reciprocal respect of the sovereignty of each and every one of the other tates of the civilized world, and in the second place, the principles which guide the doctrine of Pan-Americanism which hallow the inviolability of American national1ties; princlples which may be said to have found their highest virtues in the many offlcial declarations off the learned President of the United states. 147

147 Dominican Miniater Armando Perez Perdomo's protest. delivered on December 4, 1916 is quoted in Welles, op.cit.. II. P. 796 . 
CHAPTER IV

CONCLUSION

Drawn by the Iucrative trade prospects of the Caribbean in the later part of the eighteenth century, the United states soon found herself playing an active role in the affairs of Hispantola during the early years of the nineteenth century. United States involvement deepened with the proclamation of the Monroe Doctrine in 1823 when Washington committed herself to a policy designed to prevent European incursion into the Western Hemisphere.

Encouraged by Dominican politicians who feared Haitian conquest, the United States flirted with the Idea of annexation during the $1850^{\prime} \mathrm{s}$. Civil War cut short these notions, but the Spanish occupation, although fallure, aroused a greater determination on the part of Washington that the island Republic should never agaln be dominated by a European power. Thls determination led to a policy of annexation by the Grant administration which favored united States expansion in the Caribbean. Congress, however, did not accept the argument that expansion was necessary to prevent European encroachment, and the proposals of President Grant were defeated. 
Although expansionist profects were henceforth vlewed with disfavor, Washington st111 1nsisted that European powers be excluded from the Caribbean. When Dominican Indebtedness led to the threat of possible European Intervention, President Theodore Roosevelt moved swiftly to block any expansionist designs European powers might have entertained. With the promulgation of his Coroliary to the Monroe Doctrine, he was able to forestall any European advance In the Caribbean by establishing a customs recelvership which satisfled forelgn creditors and malntained the Domintcan Republic's soverelgnty.

Roosevelt had hoped his pollcles would bring peace to the Dominican Republic, but by 1912 it became ovident that such hopes were not to be reallzed. President wilson adhered to the eatablished policy in regards to European expansion in the Caribbean but broadened the role of the Unitad States in the domestic policies of the Dominioan Republic by Insisting on the establishment of a constitutional democracy, which in his wind was necessary to put an end to the endless cycle of revolution. If the Dominlcans could but learn the ways of democracy, he reasoned, then the cheotic conditions which invited forelgn encroachment would cease to exist. When it became apparent that democracy was not so easily Induced, w11son took the final step and sent United states Marines to occupy the Republic and instruct 
98

the Dominicans in the ways of democracy.

In sum, United states insistence that the Dominican

Ropub110 must never be dominated by a European power encouraged a variety of foreign policy decisions designed to achieve this end. Depending on the Ideological bent of the administration in power, these decisions ranged from attempts at outright annexation and financial control to a military occupation. 


\section{A BIBLIOGRAPHICAL NOTE}

As the scope of this reading 11 at is enall, the concerned student who wisheg to explore facets of Domin1can history other than the one presented in this thesis would do well to consult other blbllographical alds, the most important of which are the following: Samual E. Benis and Grace Gardner Griffin, Gulde to the Diplonatic H1story of the United States, 1775-1921 (Washington, 1935, reprinted 1959), a soholarly complation of staggering proportions. H.B.B. Hayer, Ilet of References on the Monroe Doctrine (Washington, 1919) and Ph1111p Bradley, Blbl1ography of the Nonroe Doctrine, 1919-29 (Iondon, 1929) contaln the wore important materials up to that time. Mater1als of more recent date may be obtained by consulting J.P. Harriaon, Guide to Haterials on Iatin America in the Latlonel Archives (Washington, 1961).

Uaeful blbllographlcal tools, other than thoee aseoclated with forelgn relations, are R.A. Humphreys" Latin American History: A Gulde to the Literature in English (London, 1958), especially useful to the etudent unacquainted with Iatin Amarica, and the always beneficial Pan AmerIcan Union's Index to Latin American Periodical Literature, $1929-1960$ (Boston, 1962 ). 
The student who wishes to peruse recently written materlals on the Dominican Republic would do well to consult the Handbook of Latin Anerican studies (Cambridge and Galnesville, 1936-), Public Affalrs Information Service (New York, 1915-), and the Reader's Gulde to Perlodical Lterature (New rork, 1900-).

Dominican history has suffered neglect both within 1 ts borders and abroad. Censorshlp under a number of dictators, ranging from Báez to Truj1110, has reduced the number of worthwhile Dominican studies to a trickle, while materials written abroad by exiles are almest impossible to obtaln. By far, the best history in English of the Dominican Republic covering the pre-rruj1110 period $1 \mathrm{~s}$ Smmer Welles' Naboth's Vineyard: The Dominican Republic, 1844-1924 (2 vols, New York, 1928). Written by a justly famaus diplomat, it containa much material obtalned from Dominican writers as well as Irom the archives of the state Department of the Un1ted states. A sympathet1e view of Dominican history is presented by otto schoenrlch, santo Doningo: a Country with a Future (Now York, 1918). Raadable surveys which Include materlal on Truj12lo are selden Rodman, Gulegueya, a History of the Dominican Republic (Seattle, 1964), Rayford $W$, Iogan, Hait1 and the Dominican Republ1e (New York, 1968), and John Edwin Fagg, Cuba, Lait1, and the Domintcan Republic (Englewood C11fes, 1965). 
Mary Troudley, The Onited states and Santo Damingo, 1789-1866 (Worcester, 1916, reprinted from Journal of Race Development, VI, July and October 1916, pp. 83-145, 220-74), Charles Callan Tans111, The United States and Santo Domingo, 1798-1873, a Chaptex in Caribbean Diplomacy (Baltimore, 1938), and C.C. Hauch, "Attitudes of roreign Governments towards the Spanish Reocoupation of the Dominican Republic," Hispanic American Historical Revlew, XXVII (1947), pp. 247-68, are the major studies in nineteenth century Dominican diplomatic history. Rayford W. Logan, The Diplomatic Relations of the United States with Halt1, 1776-1891 (Chapel H111, North Carolina, 1941), L.I. Montague, Haiti and the United States, 1714-1938 (Durham, North Carolina, 1940), and C.I.R. James, The Black Jacoblns: Toussaint I' Ouverture and the San Domlngo Revolution (Hew York, 1963) are valuable for the perlod before 1844 .

Dana G. Munro, Intervention and Dollar D1plomecy in the Caribbean 1900-1921 (Princeton, 1964) is a superior analysis of early twentieth century Dominican-united states relations. Its value is enhanced by the fact that Munro was given access to state Departwent flles. Studies which rely in large part on printed materisl such as Welles" rolume and rorelgn Relations are Grahan H. Stuart, Latin America and the United States (New York, 1943), W11frid Hardy Callcott, The Carlbbean Polloy of the United States, 
1890-1920 (Baltimore, 1942), and Chester Lloyd Jones, The Caribbean Since 2900 (New York, 1936).

Valuable aumaries of United States foreign pollcy in the Caribbean may be obtained by consulting $J$. Lloyd Mecham, A Survey of Onited States-Latin American Relations (New York, 1965) and J. Fred RIPpy, The Caribbean Danger zone (New York, 1940). In connection with United states use of the Monroe Doctrine the reader should not overlook the volume by Dexter Perkins entitled A History of the Monroe Doctrine (Boston, 1955).

Fundamental sources used in the preparation of this thesis Include Papers Relating to Foreign Relations of the United States, with the annual massage of the President to Congress, generally known as porelgn Relations, (Washington, 1862-) and James D. Richardson's A Compliation of the Messages and Papers of the Presidents, 1789-1897 120 vols, New York, 1917). Ulysses S. Grant in his Personal Memolrs of Ulyeses S. Grant (2 vols, New York, 1885) detalls his plang for the Dominican Republic, while Joseph Buck21n B1shop, in the volumes ontitled Theodore Roosevelt and His Time Shown in His Own Letters (2 vols, New York, 1920), demonstrates Roosevelt's anti-annexationist att1tudes. Probably the best study of Roosevelt's actions in the Caribbean during his presldency is contained in Howard C. Hill, Roosevelt and the Caribbean (Chicago, 1927). Studies relating 
to the establishment of a customs receivershlp include several articles by Jacob $H$. Hollander, the most Important of which is "The Readjustment of San Domingo's Pinances," Quarterly Journal of Economics, XXI (May, 1907), pp. 405-26. J. Fred Rippy discusses Roosevelt's action in the Dominican Republic in "The Initiation of the Customs Receivership in the Dominican Republic," Hispanlc Anerican Historical Review, XVII (1937), pp. 119-57.

studies of the military occupation may be obtained by reading Carl Kelsoy, The American Intervention in Haiti and the Dominican Republic (Philadelphia, 1922, reprinted from Annals of the American Academy of Political and Social Sclence, 100, March, 1922, pp, 109-200) and Melvin M. Knight, The Americans in Santo Domingo (New York, 1928), which is highly critical of United states policy. An immense amount of valuable data concerning the occupation is to be found in a Senate report entitled Hearings on Heiti and Santo Dominge (2 vols, 67th Congress, First and Second sessions, washington, 1922). 